\title{
CO-OPERATIVE FEDERALISM: THIRD PARTIES AND INTERGOVERNMENTAL AGREEMENTS AND ARRANGEMENTS IN CANADA AND AUSTRALIA'
}

\section{NIGEL BANKES*}

Agreements between two sovereign levels of government are both numerous and significant in modern federal states. Professor Bankes examines the effects of intergovernmental agreements on third parties in two such states, Canada and Australia. In particular, he focuses on two issues: how third parties can challenge agreements, and in what circumstances third parties can receive rights or incur obligations under them. His investigation raises questions about the impact of co-operative federalism on the interests of individual citizens.
Les accords conclus entre deux ordres de gouvernement de caractère souverain sont à la fois nombreux et importants dans les états fédéraux modernes. Le professeur Bankes examine les effets des accords intergouvernementaux sur les tiers dans le cas du Canada et de l'Australie. Il s'attache d deux problemes en particulier: comment les tiers peuvent-ils s'opposer à un tel accord et dans quelles circonstances peuvent-ils bénéficier des droits ou encourir les obligations qui y sont attachés. Son analyse soulève certaines questions quant d̀ l'impact du fédéralisme coopératif sur les intérêts des citoyens individuels.

\section{TABLE OF CONTENTS}

I. INTRODUCTION ..................... 792

II. CHALLENGES TO THE VALIDITY AND

IMPLEMENTATION OF AGREEMENTS $\ldots \ldots \ldots \ldots \ldots \ldots . \ldots 798$

III. THE EFFECTS OF INTERGOVERNMENTAL AGREEMENTS ON THIRD PARTIES $\ldots \ldots \ldots \ldots \ldots \ldots \ldots 810$

IV. CONCLUSIONS ...................... 837

\section{INTRODUCTION}

The purpose of this article is to examine one facet of the law of intergovernmental agreements in two federal states, Canada and Australia. There is a small but growing literature on the subject of intergovernmental agreements in the two countries but little in the way of comparative legal analysis. ${ }^{2}$ The literature, like the case law, reveals

- Associate Professor, Faculty of Law, University of Calgary.

I. This article is part of a larger project on intergovernmental agreements in Canada and Australia. I have dealt separately with constitutionalized agreements in an article to be published shortly. Both articles were completed while I was on sabbatical leave at the Centre for Comparative Constitutional studies at the University of Melboume. I would like to thank Professor Cheryl Saunders, the Director, and the staff at the Centre for their hospitality. I have benefited from the comments of Richard Cullen, Cheryl Saunders and Michael Crommelin on an earlier draft of this article. I would also like to thank Susan MacCormack for her research assistance on this topic many years ago.

2. J.O. Saunders, Jurisdicrional Issues in Canadian Water Management (Calgary: Canadian Institute of Resources Law, 1988) esp. c. 5, N. Bankes et al., "Energy and Natural Resources: The Canadian Constitutional Framework" in Mark Krasnick, research coordinator, Case Studies in the Division of Powers (Royal Commission on the Economic Union and Development Prospects for Canada) (Toronto: University of Toronto Press, 1986) at 53, C. Saunders, "Towards a Theory for Section 96: Parts 1 \& 2" (1987 \& 1988) 16 M.U.L.R. 1 \& 699, R. Cranston, "From Co-operative to Coercive 
considerable uncertainty as to the status of these agreements, in particular as to whether they should be governed by public law, private law or some amalgam of the two. To some extent this debate is a theoretical academic one but it becomes of practical significance when one considers what remedies may be available in the event of breach and how third parties can be affected by these agreements and arrangements. The practical utility of the subject is highlighted by the important role agreements and arrangements play in the day-to-day functioning of modern federal states. In Canada there are more than a thousand such agreements ${ }^{3}$ and in Australia one author estimates there to be at least $325 .^{4}$

This is not the place to describe in detail the different arrangements ${ }^{5}$ that have been made, but some examples will serve to illustrate their range for the purposes of the following discussion. Of greatest significance in both countries are the agreements and arrangements which support the fiscal aspects of federalism. These include cost sharing arrangements on such matters as welfare payments, tertiary education and health care. More mundane cost sharing agreements cover such things as highway construction, flood control and mineralogical surveys. In the area of natural resources both countries have complex agreements and arrangements relating to trans-boundary water resources and the management of fisheries and offshore oil and gas resources. In the environmental field there are agreements dealing with such varied matters as air and water quality standards, creation of parks and other protected areas, and co-operative impact assessment regimes.

The functions that intergovernmental agreements serve are equally varied. Some bring about a reallocation of resources at a high constitutional ${ }^{6}$ or quasi-constitutional level or bring about de facto constitutional amendments. Others have the effect of reversing what are seen to be awkward judicial decisions or of filling gaps in a regulatory regime which cannot be exclusively federal or local. ${ }^{7}$ Still others are designed to adjust the fiscal imbalance between governments and impose national standards and policies.

Federalism and Back?" (1979) 10 Fed. L.R. 121, I. Renard, "Australian Inter-state Common Law" (1970-71) 4 Fed. L.R. 87.

3. Canada, Federal-Provincial Programs and Activities: Descriptive Inventory, 1988-89, Ottawa.

4. K. Wiltshire, Planning and Federalism: Australian and Canadian Experience (St. Lucia: University of Queensland Press, 1986) at 140.

5. For a discussion of some of the more important Australian arrangements see R. Anderson, "The States and Relations with the Commonwealth" in R. Else-Mitchell, Essays on the Australian Constitution, 2d ed. (Sydney: Law Book Company, 1961) at 93-112.

6. Constitutionalized agreements are discussed in the article referred to in note 1, supra. By quasiconstitutional agreements I have in mind agreements like the offshore agreements in both Canada and Australia as to which see C.D. Hunt, The Offshore Petroleum Regimes of Canada and Australia (Calgary: Canadian Institute of Resources Law, 1989). These agreements are not constitutionally entrenched but they bring about a fundamental redistribution of resources within the federal system. R. Cullen, "Canada and Australia: A Federal Parting of the Ways" (1989) 18 Fed. L. Rev. 53, R. Cullen, Australian Federalism Offshore, 2d ed. (Intergovernmental Relations in Victoria Program, 1988).

7. The classic examples here are the marketing arrangements like the Australian Wheat Board and the Canadian egg marketing schemes as well as agreements relating to the regulation of particular industries such as the Australian coal industry. 
It is clear from this brief statement of the different types and functions of these agreements that they will often vitally affect the lives and interests of third parties. For example, an individual grain grower may have no choice as to where she markets her grain. A welfare recipient may have to comply with eligibility criteria imposed by both levels of government. The holder of a water right in one jurisdiction may have her allocation determined in part by the terms of an intergovernmental water apportionment agreement.

Such agreements give rise to a range of legal questions. I shall attempt to answer some of these questions in the course of this article. In particular, I hope to answer the following:

1. In what circumstances may a third party challenge the validity of ${ }^{8}$ or mode of implementation of an intergovernmental agreement?

2. In what circumstances will a third party be affected by, or be able to claim benefits provided under, an intergovernmental agreement?

A word on my terminology is perhaps appropriate at this stage. I have chosen to use the terms agreement and arrangement because together they embrace the full range of intergovernmental schemes that have been adopted in the two countries. I do not want to confine the analysis to agreements which may be enforceable as contracts, nor do I wish to deal with that distinction here. ${ }^{9}$ Part of my reason for not doing so is that third parties are more likely to be affected by legislation implementing an agreement than by the agreement itself. Consequently, unless the legislation is conditional upon the contractual enforceability of the agreement (which is not a conclusion that will likely appeal to a $\operatorname{court}^{10}$ ), a third party may well have rights or obligations under the legislation even though the agreement is unenforceable. ${ }^{11}$

By intergovernmental agreements I mean agreements between levels of governments that are recognized in the Constitution. I will therefore not deal with agreements with municipalities. ${ }^{12}$ Neither will I deal here with what I have termed "constitutionalized

8. The analysis here is largely confined to non-constitutional attacks upon agreements. I have summarized some of the constitutional limitations on co-operative federalism infra, text to notes 31 41.

9. To this point the literature on intergovernmental agreements has focused on this question: see the references in note 1 , supra.

10. See though Magennis Pty. Ltd. v. Commonwealth (1949), 80 C.L.R. 382 where the court held that (1) Commonwealth legislation implementing the agreement was beyond power, (2) therefore the agreement was invalid, and therefore that (3) the state legislation which implemented the agreement must also be invalid.

11. See for example Gilbert v. Western Australia (1961-62), 107 C.L.R. 494.

12. I am also excluding, more or less arbitrarily, agreements between recognized governments and aboriginal peoples but it should be noted that some of the problems discussed in this article have analogies in the Canadian jurisprudence on treaty interpretation: e.g. is an Indian treaty an international agreement, a private contract or sui generis, what legal principles should apply to their interpretation? Simon v. R., [1985] 2 S.C.R. 387. May a treaty provide rights for individual Indians? May a treaty bind third parties? Saanichton Marina Lid. v. Claxton, [1989] 5 W.W.R. 82 (B.C.C.A.). 
agreements." ${ }^{13}$ My main concern will be with province/state - federal government agreements because these predominate, but much of the analysis will be applicable to agreements between states and between provinces. The most obvious examples of third parties affected by intergovernmental agreements are of course members of the public, but other state or provincial governments may equally be interested or affected in some circumstances.

\section{A. INTERGOVERNMENTAL ARRANGEMENTS AND CONCEPTIONS OF FEDERALISM AND RESPONSIBLE GOVERNMENT}

The above description of existing interjurisdictional agreements and arrangements suggests that they are considered essential to the effective functioning of the modern federal state. However, they are at odds with traditional conceptions of federalism (coordinate federalism) and with Westminster-style responsible government. Co-ordinate federalism ${ }^{14}$ emphasises the independence and co-ordinate nature of governments in a federal system, while at the heart of responsible government is the dual notion of an executive collectively responsible to a single parliament for the business of government and of an individual minister of the Crown responsible for the conduct of affairs in her department. The creation of dual administrative structures or of ministerial councils which derive jurisdiction from each level of government, and perhaps operate by majority vote, strikes at the heart of these principles. ${ }^{15}$

Many of the criticisms that are frequently made of unchecked federal spending powers ${ }^{16}$ (often implemented through the medium of agreements that take the form of conditional grants) can also be made of intergovernmental agreements in general: they increase the power of central governments and the authority of the executive rather than that of elected representatives, they compromise political accountability, they bring about de facto backdoor constitutional amendments, they diffuse the efforts of lobbies and

May the Crown owe trust-type duties to a portion of the population? Guerin v. R., [1984] 2 S.C.R. 335, Pawis v. R. (1979), 102 D.L.R. (3d) 602 (F.C.T.D.). These questions may become more acute given the constitutional entrenchment of treaty rights: Sparrow v. R. (1990), 46 B.C.L.R. (2d) 1 (S.C.C.). There is no counterpart in Australian law to this jurisprudence.

By the term "constitutionalized agreement" I mean an agreement which is entrenched and therefore cannot be unilaterally amended, rescinded or "repealed" by either party. By their very nature therefore these agreements constitute a limitation on legislative power. See article referred to in note 1, supra.

14. K.C. Wheare, Federal Government, 4th ed. (London: Oxford University Press, 1963) at 10: "By the federal principle I mean the method of dividing powers so that the general and regional governments are each, within a sphere, co-ordinate and independent."

15. See C. Howard et al., The Co-operative Companies and Securities Scheme, Information Paper 4, Intergovernmental Relations in Victoria Program, Law School, University of Melbourne, 1982 at 27 28.

16. See D.V. Smiley, Conditional Grants and Canadian Federalism: A Study in Constitutional Adaptation (Toronto: Canadian Tax Foundation. 1953), A. Petter, "Federalism and the Myth of the Federal Spending Power" (1989) 68 Can. Bar Rev. 448, J.A. Maxwell, Federal Subsidies to Provincial Governments in Canada (Cambridge: Harvard University Press, 1937), K. Wiltshire, Planning and Federalism: Australian and Canadian Experience (University of Queensland Press. 1986) esp. chapter 6. 
pressure groups, they permit provincial/state governments to avoid and transfer their responsibilities, they insulate joint bodies from access to information legislation or from judicial review or at the very least complicate those processes, and they may delay necessary reform. ${ }^{17}$ Obviously, not all of these criticisms will be applicable all the time. However, by their very nature intergovernmental agreements tend to be executive acts, ensuring a tendency to secrecy which the subject matter often cannot justify. ${ }^{18}$ Even where legislative ratification is required, the influence of elected members may be insignificant. For example, legislative intervention may take the form of merely empowering a minister of the Crown to negotiate an agreement with another government. Alternatively, the final agreement may be presented for parliamentary approval but supported as a government measure and with the warning that any alterations by parliament will jeopardize the fragile consensus it represents. ${ }^{19}$

In addition to these more general concerns, the case law illustrates some particular problems which have been encountered: agreements may be used to evade constitutional strictures that apply to only one level of government ${ }^{20}$ such that one government becomes a mere conduit for the other, ${ }^{21}$ by shifting responsibility for funding and service delivery they complicate attempts to pinpoint legal accountability; ${ }^{22}$ policy differences in their implementation may make it extremely difficult for affected persons to obtain

See Cranston, supra note 2, at 124-125 and 136-137.

Howard et al., supra, note 15 at 37-39. Professor Cheryl Saunders, the leading Australian commentator on the legal aspects of fiscal federalism, has written that "Intergovernmental arrangements in Australia in practice have become largely the domain of executive government, whatever the theory might be. Parliaments and the public probably know less about intergovermmental activity than about any other category of governmental endeavour." Saunders, "Government Borrowing in Australia" (1989) 17 M.U.L.R. 187 at 199. Although freedom of information legislation may well make special provision for intergovernmental dealings, courts and review agencies may still be unduly deferential especially where one government has not adopted access legislation: Arnold v. Queensland (1987), 73 A.L.R. 607, Freedom of Information Act, s. 33A (Cwth.), Access to Information Act, R.S.C. 1985, c. A-1.

19. See Wiltshire, supra, note 4 at 151 .

20. Moran (W.R.) Pty. Ltd. v. Deputy Federal Commissioner of Taxation (N.S.W.) (1939), [1940] A.C. 838, 61 C.L.R. 735, Glasson v. Parkes Rural Distributions Pty. Ltd. (1984), 155 C.L.R. 234, Grasstree Poultry Enterprises Pty. Lid. v. Bycrofi (1969), 119 C.L.R. 390. College v. Minister for Education (1985), 58 A.L.R. 527 (F.C.A.).

See for example the trials and tribulations of Mr. Finlay in his attempts to vindicate his welfare claim, first against the Manitoba government, and then against the federal government on both standing and the merits, discussed in detail infra. Sometimes intergovernmental agreements may be used to compromise litigation in which third parties may have a real interest. As a result, a public interest may be suppressed. See for example the litigation on the Nechako River system which was settled by agreement forcing other interested parties to commence other actions: A.G. Canada v. Aluminum Co. of Canada (1987), 10 B.C.L.R. 371 (C.A.), Carrier Sekani Tribal Council v. Canada (Minister of Environment) (14 May 1991), (F.C.T.D.) [unreported]. 
compensation; ${ }^{23}$ and finally, by transferring decisions to hybrid intergovernmental structures they may cause both legal and political accountability to evaporate. ${ }^{24}$

These difficulties, which are revealed in the case law of both Canada and Australia, call into question the common assumption that co-operative federalism is something to be striven for. The cases suggest that while agreements may be in the interest of executive government they may be contrary to the interest of the individual citizen and may undermine such important values as accountability and responsiveness. Nevertheless, with few exceptions, the courts, still enthralled with the virtues of co-operative federalism, are unwilling to question its more dubious side effects. It is part of the thesis of this article that the courts should become more discerning in their treatment of intergovernmental agreements and arrangements. In particular they must recognize the reality that third parties are directly affected by these agreements and must review them in that light. Governmental convenience should not be a sufficient test of validity; the use of privity as a shield to judicial review has a particularly hollow ring in this context. Courts must recognize, as indeed some have, ${ }^{25}$ that intergovernmental agreements are as much instruments of public law as they are of private law. ${ }^{26}$

It is necessary to enter a caveat at this point. I am not making the claim that the courts represent a panacea for the problems of intergovernmental arrangements or that all such arrangements are amenable to judicial intervention. Rather, I am making the more modest claim that the political process by itself is inadequate to ensure accountability and responsiveness and that the courts must shoulder their share of the responsibility to ensure that the needs of co-operation do not prejudice fundamental values. Obviously we cannot ignore the political process, and some of the concerns referred to above can only be dealt with at a political level. We have a process for enacting statutes; what we need is a political process for negotiating and implementing intergovernmental agreements as well as a legal process which helps ensure accountability. ${ }^{27}$

\section{B. A COMPARATIVE ANALYSIS}

Although both countries have considerable experience with the administration of intergovernmental agreements and arrangements, neither can be said to have a coherent

Manitoba Fisheries Ltd. v. R. (1975), 58 D.L.R. (3d) 119 (F.C.T.D. motion to strike), (1976), 72 D.L.R. (3d) 756 esp. at $766 \& 768$ per Collier J. (F.C.T.D.), aff'd (1977), 78 D.L.R. (3d) 393 (F.C.A.), rev'd [1978] 6 W.W.R. 496 esp. at 508-510 (S.C.C.): a federal-provincial agreement was negotiated to regulate the freshwater fishery, the plaintiff was put out of business by federal legislation but the province was given the responsibility to compensate; no compensation was ever paid.

24. Tasmanian Wilderness Society v. Fraser (1982), 153 C.L.R. 270.

25. See for example the Reference Re Canada Assistance Plan, (1990), 71 D.L.R. (4th) 99 (B.C.C.A.), Prince Edward Island v. Canada, [1976] 2 F.C. 712 (T.D.), rev'd on the damages issue [1978] 1 F.C. 533, Re Taxation Agreement Between Government of Saskatchewan and Government of Canada, [1946] I W.W.R. 257 (Arbitration Board).

26. See Saunders, supra, note 2.

27. The legal process is not the only process available. Reference must also be made to the functions of the auditor-general, the ombudsperson and access to information legislation. 
body of law on the subject. Each jurisdiction supplies but a handful of decided cases, although the Canadian material is somewhat richer. The problems raised by these arrangements are common to both jurisdictions and it is fruitful to examine how they have been dealt with in each. One jurisdiction may suggest solutions to the other and open up new lines of inquiry. Comparative analysis has its dangers, however, if one fails to appreciate relevant differences in the constitutional framework of the two countries. Although it has often been remarked that the federal government in Australia has significantly more legislative authority than its Canadian counterpart, that does not seem to be of great significance here. The same can be said of the fact that while the Australian Constitution lists only the federal heads of power, the Canadian Constitution lists both federal and provincial powers. Instead the more important distinctions for this paper would seem to be the positive support provided by s. 96 of the Australian Constitution for federal conditional grants $\mathrm{s}^{28}$ and the greater legalism of the Australian High Court. ${ }^{29}$ We must also keep in mind possible differences in the substantive and procedural law of the two countries, notably in the law of standing.

Ultimately, however, as an exercise in comparative law the results of the research are somewhat inconclusive if not disappointing. By contrast with other areas of constitutional and administrative law, there is little or no cross-fertilization between the two systems in this field, at least at the judicial level, even though both systems face very similar problems. We shall now turn to the first of the questions posed above.

\section{CHALLENGES TO THE VALIDITY \\ AND IMPLEMENTATION OF AGREEMENTS}

\section{A. INTRODUCTION}

A third or non-party wishing to challenge either the validity or the implementation of an intergovernmental agreement faces two major obstacles: one created by private law, privity of contract, and the other primarily a doctrine of public law, standing. In both cases the foundation of the objection is essentially the same: this plaintiff has an insufficient interest to contest the validity of this agreement and, even more clearly, has no right to complain that it is not being implemented in accordance with its terms. Both objections ignore the claim that we have made above that these agreements are public agreements and vitally affect the interests of third parties.

A third difficulty is faced by anybody who wishes to challenge the implementation of an agreement. The claim here will usually take the form of an assertion that a government should be obliged to live up to the terms of an agreement and honour

Section 96 provides that "the Parliament may grant financial assistance to any State on such terms and conditions as the Parliament thinks fit."

29. See generally, Christopher D. Gilbert, Australian and Canadian Federalism, 1867-1984: A Study of Judicial Techniques (Carlton, Victoria: Melbourne University Press, 1986). Reference might also be made to the contrast between the Canadian judicially created prohibition on interdelegation and the authority of the Commonwealth parliament to legislate in relation to matters referred by the states under placitum 51 (xxxvii). 
conditions contained in it. The difficulty with this claim, when raised by a third party, is that it seems to involve the proposition that the agreement should act as a limitation on legislative power, a proposition that is untenable unless the agreement itself is constitutionalized. ${ }^{30}$ There is a partial solution to this difficulty in the form of a principle of interpretation, but this will not carry the argument if the implementing legislation is clear; a point which is discussed in more detail below.

\section{B. CHALLENGES TO THE VALIDITY OF AGREEMENTS BY THIRD PARTIES}

A third party is likely to have an easier time challenging the validity of an agreement than its mode of implementation. The third party need assert no cause of action and need seek only a declaration that the agreement is invalid. The most serious obstacle will be the procedural concerns of standing and privity.

A challenge to the agreement itself will most likely be made on constitutional grounds. ${ }^{31}$ In Australia agreements have been challenged (unsuccessfully) on the grounds that they interfere with interstate trade, ${ }^{32}$ that they create joint structures in a manner that is inconsistent with federal principles, ${ }^{33}$ or that they allow the Commonwealth to discriminate between states in the incidence of tax $;^{34}$ or (successfully) on the ground that they purport to allow the Commonwealth to acquire property on other than just terms. ${ }^{35}$ Challenges on the ground that the agreements infringe federal spending powers are unlikely to be mounted because of the broad interpretation that the High Court has accorded to the Commonwealth's conditional grants power under s. $96^{36}$ as well as the spending power based upon ss. 61,81 and 51 (xxxix) of the Constitution. ${ }^{37}$ In Canada agreements are most likely to be challenged on the grounds that they infringe the judicially created prohibition on legislative interdelegation ${ }^{38}$ although increasingly

See Magennis, supra, note 10 per McTiernan J. (in dissent) and Milne v. A.G. Tasmania (1956), 95 C.L.R. 460 at 464 dealing with the Commonwealth-Tasmanian agreement: "The agreement, of course, was purely a matter between the Commonwealth and the State. On the one hand it conferred no rights upon anybody. On the other hand, it did not limit in any way the constitutional powers of the State."

31. The topic of constitutional limitations on co-operative federalism in general and intergovemmental agreements in particular is deserving of an article in itself. What follows is only the barest of outlines. For an early Canadian study see L.M. Gouin and B. Claxton, Legislative Expedients and Devices Adopted by the Dominion and Provinces, A Study Prepared for the Royal Commission on Dominion-Provincial Relations (Ottawa: King's Printer, 1939). Clark King \& Co. Pty. Ltd. v. Australian Wheat Board (1978), 140 C.L.R. 120, Uebergang v. Australian Wheat Board (1980), 145 C.L.R. 266, Wilcox Mofflin Lid. v. New South Wales (1952), 85 C.L.R. 488. Re Duncan (1983), 49 A.L.R. 19; Re Cram (1987), 163 C.L.R. 117.

Moran's Case, supra, note 20.

Magennis's Case, supra, note 10.

Moran's Case, supra, note 20, Glasson v. Parkes (1983), 155 C.L.R. 234, Victoria v. Commonwealth, Roads Case (1926), 38 C.L.R. 399, South Australia v. Commonwealth, First Uniform Tax Case (1942), 65 C.L.R. 373, A.G. Victoria v. Commonwealth, DOGS Case (1981), 146 C.L.R. 559. 
that ground of review is becoming a paper tiger ${ }^{39}$ as governments have been adept for many years at avoiding its artificial constraints. ${ }^{40}$ Attacks on spending power grounds are not likely to succeed. ${ }^{41}$

In addition to these constitutional grounds it is possible to envisage other grounds for attack, such as that a particular agreement should have been approved by statute or approved by the premier's office. These arguments go to the authority to enter into the agreement. . It seems to be accepted by the courts in both Canada and Australia that, as a matter of common law, the Crown has a wide power to contract and does not need specific statutory authorization. ${ }^{42}$ There is no reason to think that the courts would take a different view of agreements (and especially arrangements) between two governments. ${ }^{43}$ Certainly any reliance upon the supposed indivisibility of the Crown as a means of contesting the agreement seems doomed to failure. ${ }^{44}$

An attack upon an intergovernmental arrangement will therefore have to find support in a specific statutory provision. The argument will also have to establish that the requirement is a matter of substance rather than form. ${ }^{45}$

In Carota v. Jamieson ${ }^{46}$ the plaintiff, a resident of Prince Edward Island, questioned the validity of a federal-provincial agreement on the grounds that the federal government had acted in breach of its authorizing legislation. ${ }^{47}$ Basically, Carota's claim was that the government was obliged to consult with local groups before entering into agreements of this nature with the province. His claim was rejected by both the trial court and the Court of Appeal on the grounds that the statutory provision that Carota had invoked only

K. Lysyk, "Constitutional Law - The Inter-Delegation Doctrine: A Constitutional Paper Tiger?" (1969) 47 Can. Bar Rev. 271.

In fact the prohibition has almost become a dead letter. In two recent cases, Dick v. A.G. Canada, [1986] 1 W.W.R. 1, Peralta v. R., [1988] 2 S.C.R. 1045, the Supreme Court has dismissed claims on this point without providing detailed reasons.

4. Winterhaven Stables v. A.G. Canada, [1989] 1 W.W.R. 193 (Alta. C.A.) (leave to appeal to the S.C.C. denied, [1989] 3 W.W.R. Ixxi).

R. v. CAE Industries Ltd. (1985), 20 D.L.R. (4th) 347 (F.C.A.), State of New South Wales v. Bardolph (1934), 52 C.L.R. 455. J.E. Richardson, "The Executive Power of the Commonwealth" in L. Zines, Commentaries on the Australian Constitution (Butterworths, 1977) 50 at 72-76.

Re Duncan, supra, note 33, Reference Re Anti-Inflation Act, [1976] 2 S.C.R. 373. (The issue here was the effect of an agreement on third parties; Laskin C.J.C., for the court on this point accepted that the Crown had bound itself without the need for legislation. The case is discussed in detail, infra.)

44. P.W. Hogg, Liability of the Crown, 2d ed. (Toronto: Carswell, 1989) at 10-12.

45. Ibid. at 166-167 makes the argument that special statutory requirements for Crown contracts should generally be seen as matters of form rather than substance. This claim has been criticized but it can be accepted that it has some cogency when dealing with private parties who may have relied upon a representation made by a governmental official. It is less persuasive in the context of an intergovemmental arrangement where there is no private interest to weigh against the competing value of the public interest in ensuring lawful behaviour. addition there are two reported decisions on various interlocutory matters in which standing was discussed, [1977] I F.C. 19, and [1977] I F.C. 504, aff'd [1977] 2 F.C. 239. 
applied to situations where the federal government launched a unilateral development initiative in a region. In the court's view, the procedural protection had no application to the situation where there was an agreement. Indeed, both Marceau J. at trial and the Court of Appeal seem to have been of the view that the true authority for the agreement was a line entry in the Appropriation Act. ${ }^{48}$ Unfortunately for our purposes, that also meant that it was unnecessary for the court to deal with other issues including arguments as to standing and as to whether, if such a duty of consultation did exist, it might give rise to a private right of action. ${ }^{49}$

The attack was more successful in A.G. Canada v. Saskatchewan Water Corporation. ${ }^{50}$ This case did not involve a third party and, in form, the agreement in question was not an intergovernmental agreement. In substance, however, it was. It was designed to settle certain differences between the Saskatchewan and federal governments over the construction of the Rafferty-Alameda dam, but it was formally concluded with the Water Corporation, a Crown corporation and an agent of the Crown in right of the province. The Water Corporation resisted the federal application for an injunction on a number of grounds, including the argument that the agreement was unenforceable because of the provisions of s. 7 of the Department of the Environment Act:

The Minister may, with the approval of the Governor in Council, enter into agreements with the government of any province or any agency thereof respecting the carrying out of programs for which the Minister is responsible.

Chief Justice McPherson was of the view that the agreement did relate to a program and that the permissive "may" did not qualify the clear requirement of statutory approval. Neither was it appropriate to read the provision as merely directory, for this was not a case in which the Crown was trying to use the provision as a shield to avoid liability; rather the Crown was trying to avoid the statutory restriction and yet at the same time enforce the agreement. Consequently, he held the agreement to be unenforceable.

Subject to the rules on standing, discussed below, I would suggest that this is precisely the sort of case in which a court might entertain an action by a third party questioning the validity of the arrangement, an arrangement which had all the trappings of a backroom deal. No great violence to principle would be occasioned, for the case could be easily be treated as an administrative law application questioning the vires of the governmental action.

Appropriation Act No. 5, 1973, S.C. 1973-74, c. 47 which appropriated monies for the program, [1979] 1 F.C. 735 at $742-43$ and [1980] 1 F.C. 790 at 799.

lbid. at 798.

[1991] 1 W.W.R. 426. For another example of a legislative provision imposing requirements on the execution or ratification of intergovernmental agreements see: Department of Federal and Intergovernmental Affairs Act, R.S.A. 1980, c. D-20. This statute (s.5(1)) is considerably more explicit than the statute discussed in the case in that it provides that agreements shall not be binding in the event of non-compliance. 
These two cases highlight the point that special procedural rules may attend the negotiation of intergovernmental agreements. Given the special problems of accountability that are engendered by these agreements, the courts should be vigilant to ensure their observance, treating them as mandatory requirements unless specially directed otherwise by the legislature. In addition there would seem to be no reason in principle why these procedural requirements should not be raised by a third party.

\section{CHALLENGES TO THE IMPLEMENTATION OF AGREEMENTS}

A third party may wish to challenge the implementation of an intergovernmental agreement for a number of reasons. The most likely situation will be where an applicant believes that an agreement was intended to provide her with a benefit, but, because of the way in which it has been interpreted or implemented by one level of government, she is either not eligible or, if eligible, eligible for a smaller benefit.

Much of the Canadian litigation on the implementation of agreements is concemed with welfare entitlements under the Canada Assistance Plan. Under the CAP, the Minister is authorized by federal statute to enter into an agreement with each province to share the cost of providing welfare services on condition that the provincial scheme for providing the assistance meets certain, quite extensive, minimum requirements. This arrangement, which fosters national standards, is required because of the existing fiscal imbalance between the two levels of government and because welfare matters are a provincial responsibility except to the extent that they are subject to concurrent jurisdiction under $\mathrm{s}$. 94A of the Constitution Act, 1867. Moreover, welfare services lend themselves to local delivery and decentralized administration.

These complex arrangements spawn equally complex legal problems. The very flexibility allowed to the provinces in the way in which they meet the federal terms invites interpretive difficulties. The problems may be further exacerbated where a province chooses to involve municipal governments in assessment and service delivery. A veritable jurisdictional morass faces the aggrieved individual seeking redress from as many as three different bureaucracies, as the Le Blanc, ${ }^{51}$ Lofstrom and Murphy ${ }^{52}$ and Finlay ${ }^{53}$ cases illustrate.

In Le Blanc, the plaintiff, a resident of Manitoba, had applied for supplementary assistance. In that province the government had opted, after the introduction of the Canada Assistance Plan, to continue the delivery of welfare services through municipalities. As a result there existed two schemes for assessing need. Le Blanc's application was considered first by the City of Transcona and under their scheme he was

St.

52.

53.

Le Blanc v. City of Transcona, [1971] 4 W.W.R. 23 (Man. C.A.), aff'd [1974] S.C.R. 1261.

(1971), 22 D.L.R. (3d) 120 (Sask. C.A.).

On the application for judicial review see Re Finlay and Director of Welfare (Winnipeg South/West) (1976), 71 D.L.R. (3d) 597 (Man. C.A.) (hereinafter sometimes referred to as Finlay No. 1), on standing see Finlay v. Minister of Finance, [1986] 2 S.C.R. 607 (hereinafter Finlay No. 2) and, for the federal court action, Finlay v. Minister of Finance (1990), 71 D.L.R. (4th) 422 (F.C.A.) (hereinafter Finlay No. 3). 
denied relief. He therefore appealed to the provincial Welfare Advisory Committee. That committee applied the provincial definition of need and allowed Le Blanc's appeal. An appeal by the city to the Manitoba Court of Appeal was allowed by a majority of the court and that judgment was confirmed by a majority upon a further appeal to the Supreme Court of Canada.

The narrow issue on appeal ${ }^{54}$ was whether or not the committee was obliged to apply the municipal test of need or whether it could apply the provincial test. Framed more broadly the issue might be stated thus: in the event of an ambiguity in the provincial scheme for implementing the federal-provincial scheme, should the court prefer an interpretation that is consistent with the terms of the agreement rather than one that is at odds with it?

The majority in both the court of appeal and the Supreme Court, while acknowledging the federal-provincial origins of the scheme, preferred an interpretation that favoured the internal consistency of the provincial legislation rather than one that was consistent with the agreement. As a result they opted for the municipal test, justifying this in part by reference to notions of privity.

It may be argued [stated Spence J.] that the Province of Manitoba ... is not providing for persons in need in accordance with that requirement in the Canada Assistance Plan ... That, in my view, is a matter which must be settled between the Province of Manitoba and Canada and can have no application to an appeal by the present appellant against the refusal [to grant him an allowance]. ${ }^{\text {ss }}$

The two dissenters, Freedman C.J.M. and Laskin C.J.C., were far more sensitive to the overall context of the scheme. Freedman ${ }^{56}$ placed particular emphasis on the requirement of the Canada Assistance Plan that the level of need be "established by the provincial authority." For his part, Laskin believed that in determining the powers of the committee (which were not expressly limited by the provincial legislation) deference should be paid to ${ }^{57}$ "the fact that the Social Allowances Act was intended to meet the qualifying conditions of the Canada Assistance Plan."

The two dissenting judges did not clearly articulate the basis for their decision but, in my view, they would support the principle that where legislation is intended to implement a federal-provincial agreement, the agreement should form part of the context for interpreting the legislation and, in the event of an ambiguity, an interpretation consistent with the terms of the agreement should be preferred. Indeed one can mount a strong argument to the effect that the court should be able to have access to the agreement for the purpose of revealing a latent ambiguity in the legislation. ${ }^{58}$ Support for this approach

54. The provincial legislation provided for an appeal on a point of law or jurisdiction.

ss. [1974] S.C.R. 1261 at 1268.

so. [1971] 4 W.W.R. 23 at 26.

57. [1974] S.C.R. 1261 at 1282.

58. I. Brownlie, Principles of Public International Law, 3rd ed. (Oxford: Clarendon Press, 1979) at 5051. 
can be found in the principles of interpretation traditionally applied to legislation implementing an international treaty. ${ }^{59}$

A similar issue of consistency between an agreement and its implementing legislation arose in Re Lofstrom and Murphy. ${ }^{60}$ Strikers, who met the definition of "person in need" under the Canada Assistance Plan and the Canada-Saskatchewan Agreement, were denied social assistance by the Province of Saskatchewan which passed a regulation to that effect. The applicants then sought certiorari on the grounds that the decision had been made pursuant to regulations which were inconsistent with the Canada-Saskatchewan Agreement and the Canada Assistance Plan. This argument was rejected: ${ }^{61}$

Part I of the Canada Assistance Plan creates no right to assistance by any person in this Province. It does no more than provide the legislative authority for the Government of Canada to enter into a costsharing agreement with a provincial Government with respect to social assistance granted by the Province... To ensure that the agreement complies with the authority granted by the Act, provision is made for the incorporation of certain specific terms in the agreement. It in no way restricts the legislative competence of a provincial Legislature in the field of social assistance. If, after entering into an agreement, a Province adopts legislation and regulations contrary to the terms of the agreement, that would be a matter entirely between the Governments, affecting only the respective obligations and rights under the agreement.... In my opinion the right of any resident of Saskatchewan must be found within the provisions of the Saskatchewan Assistance Act, 1966. No rights arise by virtue of the Canada Assistance Plan.

This argument appeals to the two fundamental elements of dogma that we have already alluded to, the doctrine of parliamentary sovereignty and the doctrine of privity. In the absence of constitutional effect being given to the agreement we must accept the conclusion, in the absence of a Charter attack, ${ }^{62}$ that a province may legislate in derogation of its contractual undertakings, but we should be careful not to concede more than is necessary. It is one thing to accept that clear statutory language will have this effect, but what if the alleged breach is accomplished, as it was here, by means of delegated legislation? Then, in the absence of the clearest possible statutory language, we can adopt an alternative analysis consistent with that developed above for Le Blanc: the regulation depends for its validity on the statute which was designed to implement the

59. Legislation is to be interpreted in a manner consistent with a state's international obligations and, in the event of an ambiguity, a court may have resort to the text of the treaty to assist in its resolution. See the Acts Interpretation Act, s. 15AB (Cwth). James Crawford and W.R. Edeson, "International Law and Australian Law" in K.W. Ryan (ed.) International Law and Australia, 2d ed. (Sydney: Law Book Co., 1984) 71 at 81 and 112-117; E.A. Driedger, Construction of Statutes (Toronto: Butterworths, 1983) at 215.

60.

61.

Ibid. at 122.

62. Supra, note 52.

A Charter attack is probably most likely to be based upon s. 15 of the Charter, the equality clause. See the unsuccessful challenges to the Meech Lake Accord by the Yukon and Northwest Territories: Penikett v. R., [1988] 2 W.W.R. 481 (Y.T.C.A.), Sibbeston v. A.G. Northwest Territories, [1988] 2 W.W.R. 501 (N.W.T.C.A.). 
federal-provincial agreement. The legislature cannot have contemplated that a regulationmaking power would be used to breach the agreement. ${ }^{63}$

The third case in the trilogy is Finlay. Mr. Finlay, a resident of Manitoba, qualified for social assistance under the Manitoba scheme because of lifelong disabilities. On three occasions he was declared to have received overpayments which the province attempted to recover by making small deductions from his entitlement. As in Lofstrom and Murphy and Le Blanc, Finlay began by taking his case before the provincial authorities and superior courts, claiming that there was no authority under the Social Allowances Act to reduce his assistance below the cost of basic necessities. He was unsuccessful before both the Welfare Advisory Committee and the Manitoba Court of Appeal. Neither the Canada Assistance Plan nor the federal-provincial agreement was mentioned in the judgment of the court. ${ }^{64}$

Having been rebuffed provincially, Finlay began an action in Federal Court seeking declaratory and injunctive relief against two federal ministers: the Minister of National Health and Welfare for certifying that the Manitoba scheme met the requirements of the Canada Assistance Plan, and the Minister of Finance for making payments from the Consolidated Revenue Fund which had not been authorized by Parliament. The essence of the claim was that monies could be paid to the provincial government only in accordance with the agreement, which agreement must in turn accord with the conditions laid down by parliament. No attack was made on the agreement itself but it was alleged that the province was in breach of the agreement and therefore the disbursements were not authorized by parliament. In other words, to establish a breach of the federal statute the plaintiff had to establish a breach of the agreement.

The particulars of the breaches were that (1) the recovery of overpayments was a breach of s. $6(2)$ (a) of the agreement which required that the provincial scheme provide assistance up to the level of "basic requirements"; (2) under the provincial scheme Finlay had received payments from municipalities which were characterized as loans rather than aid; and (3) the provincial scheme delegated the authority to establish needs levels to the municipalities which was an impermissible subdelegation. (This was the issue that Spence J. had alluded to in Le Blanc.) Only the first and third issues were considered by the courts. of the court is not without interest because it shows how thin was the statutory basis on which the provincial claim to recover monies rested. The clause was precisely the sort of general clause which would have lent itself to being read down in the interests of an interpretation that was consistent with Manitoba's obligations under the federal-provincial agreement. The provincial statute was later amended to make the right to deductions clear but the point is still valid in the context of the interpretive approach that we have been developing. My argument is not assisted by a recent decision of the Nova Scotia Court of Appeal dealing with a reciprocal taxation agreement, $R e$ Canadian Broadcasting Corp. and Nova Scotia Tax Review Board (1991), 79 D.L.R. (4th) 700. 
Once he had overcome the problem of standing ${ }^{65}$ Finlay's first claim was upheld both at trial ${ }^{66}$ and on appeal. ${ }^{67}$ The courts acknowledged that under CAP and the agreement the province was entitled to establish the level of "basic requirements" but, once having done so, to reduce assistance below that level was not permitted. Although the province used slightly different statutory language than CAP ("basic necessities" rather than "budgetary requirements" or "basic requirements") the evidence did establish a reduction below budgetary requirements. ${ }^{68}$

The third argument was rejected at trial but accepted on appeal because of the precise language used in the agreement. CAP itself (i.e. the federal statute) stated that the needs test was to be "established by the provincial authority" which was in turn defined as "the provincial minister or other official or body specified by the province" in the relevant agreement. The agreement designated the Minister of Welfare. The federal government and the province made the argument, which had been accepted in Le Blanc, that this was an issue between the parties that did not concern the applicant. MacGuigan J.A. for the Court of Appeal rejected the point: "in the case at bar any question as to whether [Finlay] has the right to challenge even matters of contract between the federal government and the province has been pre-empted by the Supreme Court of Canada, which recognized [him] as having public interest standing for purposes of this case ..."69

Finlay's case offers a creative solution to some of the complex problems posed by intergovernmental agreements. It also offers a principled reason for allowing a third party to insist that governments observe the terms of their agreements, especially when they are negotiated pursuant to statutory authority. Parliament must be taken to have endorsed the arrangement and it should not readily be assumed that the executive has the authority to change it. To insist that a formal amendment be negotiated is to do no more than insist upon accountability to parliament.

The case also suggests that solutions may be phenomenally time-consuming and expensive unless a more direct remedy can be provided. In Finlay, for example, over ten years elapsed from the failure of the original application for judicial review until the matter came before the Federal Court of Appeal on the merits. The interpretive principles discussed above in relation to Lofstrom and Murphy and Le Blanc offer a partial solution. If there were the political will, appropriate drafting techniques could also be harnessed to this end. For example, the agreement might provide (1) that any implementing legislation should contain a clause to the effect that the legislation is intended to implement the agreement and is to be interpreted in a manner consistent with the agreement, and (2) that payments under the agreement would only be made where this condition had been fulfilled. This would dramatically improve the prospects for success in the provincial superior courts and, at least at a formal level, would not compromise the sovereignty of provincial legislatures. Only egregious departures from the terms of the agreement would 
escape review by the provincial superior courts. Such egregious problems might be dealt with more readily by the governments themselves; failing that, parties could still resort to a review of the actions of federal officials as in Finlay.

The Australian case of Gilbert v. Western Australia ${ }^{70}$ illustrates the utility of the interpretive approach. Gilbert is one of a series of cases ${ }^{71}$ dealing with various aspects of Commonwealth-state agreements on the settlement of veterans after World War II. The state provided the land and the Commonwealth covered a portion of the costs. Initially, the implementing legislation of the state was very closely linked to the agreement, but after the Magennis case in which the original arrangement was struck down for breach of the constitutional provision on the acquisition of property on just terms, the arrangements were recast. The new scheme was crafted as a conditional grant arrangement so as to enjoy the protection of $\mathrm{s} .96$ of the Constitution. ${ }^{72}$

Gilbert had availed himself of the program and had obtained a leasehold title from the state. The dispute between the parties arose over the price at which he was to be able to exercise the right to purchase the reversion. The state Act authorized the Minister to fix the purchase price "under the scheme." But what did this mean? The Minister took the view that he had" ${ }^{73}$ "a complete discretion or power to fix the price, that in its exercise he need only have regard to the general purposes of the scheme as a political and administrative concept, and that his decision is in no way controllable or examinable by the court." The court rejected that argument in a unanimous judgment. In their view the "scheme" meant the conditions imposed by the Commonwealth which replaced the terms of the agreement, and the Minister must comply with them in order to provide Gilbert with a valuation fixed according to law.

There is nothing unusual about this case, for the result was determined by the terms of the state legislation. The agreement had not worked a limitation on state legislative power but, since the state had incorporated the scheme by reference in its legislation, Gilbert was entitled to insist that the state comply. Perhaps the state regretted its decision to refer to the scheme, but, on the view taken above, this type of drafting technique should be more widely adopted.

\section{SUMMARY}

We have seen that, subject to problems of standing, the validity of intergovernmental agreements may be challenged either on constitutional grounds or administrative law vires grounds. Since both are avowedly public law challenges, privity of contract arguments have not been raised in defence. The same cannot be said of challenges where the argument is that state or provincial legislation has failed to implement the agreement. Here the plaintiff faces more serious hurdles. 
Such a case needs to be framed very carefully if it is to succeed. Since an ordinary intergovernmental agreement cannot act as a limitation on legislative power, a direct attack on provincial or state implementing legislation will fail. However, I have suggested that in at least some cases the desired result can be achieved if the courts can be persuaded to adopt, as a principle of interpretation, the guide that statutes intended to give effect to intergovernmental agreements should be interpreted in a manner consistent with the fulfilment of those agreements. Appropriate drafting techniques such as those adopted in Gilbert can make it easier for the courts to adopt this approach, but support for it can also be drawn from the principles utilized by the courts for interpreting statutes designed to implement international agreements. Approached this way it is clear that the problem is properly viewed, once again, as a matter of public law. Consequently the absence of privity should be irrelevant, but the cases, especially Lofstrom and Murphy and Le Blanc, have suggested a different view. In my opinion the approach suggested in Finlay No. 3 is to be preferred and the problem seen as one of standing.

Finally, Finlay No. 3 also suggests an alternative if the interpretive approach fails. Consistency between agreement and legislation may be urged by alleging that appropriations are unlawful for as long as the provincial/state implementing scheme fails to comply with the nationally imposed conditions. This approach, which turns on the precise statutory language, is very indirect and therefore raises a serious problem of standing. It also lacks precision, for the remedy cannot be specific to the needs of the individual litigant. Nevertheless, as a technique for forcing governments to be accountable to their written agreements it has great merit.

\section{E. EXCURSUS: STANDING}

It is probably safe to conclude that Finlay, Lofstrom and Murphy, and Le Blanc all commenced their actions in the provincial superior courts at first instance because it presented the most direct and local point of attack, but there was also a sound legal reason in the form of the rules on standing. There was obviously no difficulty with standing in the provincial superior courts, for the applicants had all been directly affected by a decision of the provincial welfare agencies. By contrast, an attack on the federal legislation was attended by significant risk because none of the applicants could claim a direct interest in it. ${ }^{74}$ They were not directly entitled to federal money, nor could success in their action by itself make them eligible for benefits under the provincial scheme. These indeed were the reasons that the Supreme Court gave in Finlay No. $2^{75}$ for denying the plaintiff standing, in his own right, in his federal court action. The Court simply applied the usual rules for standing for a declaration or injunction in nonconstitutional cases. In such cases, dealing with public rather than private rights, both the

This would seem to have been the point that Dixon J. was making in his dissenting judgment in the Magennis case, supra, note 10, at 412 (the first of the veterans' land cases, see the discussion of Gilbert, supra) in which he suggested that the plaintiff had no standing to contest the validity of the Commonwealth legislation in the absence of a conclusion that the state legislation was dependent for its validity on the agreement and the Commonwealth statute. 
Canadian and Australian ${ }^{76}$ courts demand that the plaintiff show some interest beyond that of the general populace. An intellectual, emotional, or genuine interest will not suffice. In the absence of a qualifying special interest, the only appropriate plaintiff is the guardian of the public interest, the Attorney General, either personally or in a relator action; the court has no discretion to hear anybody else. ${ }^{77}$

For a number of years the Supreme Court of Canada has refused to apply these rules to constitutional and quasi-constitutional litigation. In Thorson, ${ }^{78} \mathrm{McNeil}^{79}$ and Borowsk $^{80}$ (the last dealing with the Bill of Rights and the first two with division of powers problems), the court applied the basic value that a citizen has an interest in the constitutional behaviour of governments. Hence standing might be accorded to a private individual, in the discretion of the court rather than as of right, where three conditions were met. First, the issue raised must be a justiciable one. Second, the plaintiff must be able to establish a genuine interest and be more than just a busybody. Finally, the plaintiff must be able to establish that the attorney general either would not lend his or her name, or, by the nature of the litigation, would be unlikely to do so and that there was no obviously better plaintiff who would be likely to challenge the government's behaviour. In Finlay No. 2 the court applied these tests to the non-constitutional ${ }^{81}$ setting of the Canada Assistance Plan, the underlying rationale being the public interest in the lawful behaviour of governments.

On justiciability the Attorney General for Canada argued that the plaintiff could not establish his case. In reality this was simply a privity argument in a different guise and couched in slightly different terms. The question of provincial compliance with an intergovernmental agreement was, it was argued, not an appropriate matter for judicial determination, rather it was ${ }^{82}$ "one that should be left to government review and intergovernmental resolution." Le Dain J. for the Supreme Court rejected that argument, noting that the issues raised by the plaintiff's case were legal issues. It by no means followed that the same could be said of all issues raised by federal cost-sharing arrangements. ${ }^{83}$

The second test was easily met by Finlay. Nobody could seriously contend that he did not have a genuine interest in the validity of the federal payments and he was far from being a mere busybody. Similarly, nobody could doubt his suitability as plaintiff. As Chief Justice Thurlow stated in the Federal Court of Appeal, neither the province nor the municipalities had any interest in having the matter adjudicated and the federal Attorney

Australian Conservation Foundation v. Commonwealth (1978-79), 146 C.L.R. 493.

Gouriet v. Union of Post Office Workers, [1978] A.C. 435 (H.L.).

Thorson v. A.G. Canada, [1975] I S.C.R. 138.

Nova Scotia Board of Censors v. McNeil, [1976] 2 S.C.R. 265.

Minister of Justice (Canada) v. Borowski, [1981] 2 S.C.R. 575.

Supra, note 75. A mere administrative law case at one level but at another level raising a quasiconstitutional matter. It is surely more than coincidence that the Supreme Court chose to extend the constitutional trilogy in a decision dealing with intergovernmental agreements.

Ibid. at 615 .

Ibid. at 632 . 
General was interested in upholding the validity of the scheme. ${ }^{84}$ In short there could be no better plaintiff.

The decision in Finlay has significantly liberalized the law of standing in Canada and renders possible an indirect way of insisting that intergovernmental agreements be performed in accordance with their terms. Thus far, Australia has failed to follow this lead in either constitutional ${ }^{85}$ or non-constitutiona ${ }^{86}$ cases, although it remains very much open for argument in the former class. ${ }^{87}$ In my view Finlay No. 2 represents an appropriate extension to the laws of standing given the difficulties engendered by intergovernmental agreements for individual litigants and given the reluctance of either federal or provincial attorneys-general to address themselves to the problem.

We shall now turn to the second question that we posed at the outset, namely, under what circumstances will a third party be affected by, or be able to claim benefits provided under, an intergovernmental agreement?

\section{THE EFFECTS OF INTERGOVERNMENTAL AGREEMENTS ON THIRD PARTIES}

The general principle of Anglo-Australian-Canadian contract law is that third parties cannot enforce a right or benefit under an agreement to which they are not a party. This doctrine has been the subject of considerable criticism over the years, but although the courts have crafted some exceptions it still retains its basic vitality ${ }^{88}$ and has been applied on many occasions in the context of intergovernmental agreements. Indeed we have already seen the argument raised in the context of challenges to the validity or implementation of an agreement. A second principle is at least as influential in the present context, namely that the rights of subjects can only be affected by a law validly passed.

This second half of the paper is divided into four separate sections. The first and shortest part deals, for the sake of completeness, with the effect on third parties of property transactions between governments. The second and third parts deal with the effect of executive or statutory approval on the position of third parties. The final part considers the possibility that even in the absence of statutory approval a third party might be able to obtain enforceable benefits under an intergovernmental agreement.

84. [1984] 1 F.C. 516 at 526-27.

85. G.D.S. Taylor, "Standing to Challenge the Constitutionality of Legislation" in L.A. Stein (ed.), Locus Standi (Sydney: Law Book Co., 1979) at 143-72.

88. See though Trident General Insurance Co. v. McNeice Bros. Pty. Ltd. (1987), 80 A.L.R. 574. At its narrowest this case established that the rules that only a party to a contract can sue on it and that consideration must move from the promisee do not apply to a policy of insurance. Some of the judgments support a broader attack on the doctrine of privity. 


\section{A. PROPERTY TRANSACTIONS: A SPECIAL CASE}

Property transactions between governments represent a minor exception to the general propositions on privity but one which is perfectly consistent with principles of property law. Thus, transfers from one government to another will affect the entire world, partly as a matter of property law but also because of the consequences for legislative jurisdiction. A transfer from a province to the federal Crown will cause the property to become subject to federal legislative competence under s. 91(1A) even though the lands will continue to be part of the province. ${ }^{89}$ Essentially the same position prevails in Australia under s. 52 of the Constitution. ${ }^{90}$ Some have suggested therefore that interjurisdictional transfers should receive special parliamentary scrutiny, and this does seem appropriate. ${ }^{11}$

The effects of a property transfer on third parties will be very indirect. Interests in the land held by third parties will certainly carry over and be exercisable against the transferee. ${ }^{92}$ By the same token public rights such as the right of passage on a highway will not be affected by a transfer of property. ${ }^{93}$

\section{B. EXECUTIVE AGREEMENTS UNSUPPORTED BY LEGISLATION}

Property transfers therefore represent something of a special case. This category of transactions apart, criticism of the doctrine of privity has focused on the issue of contractual rights, for nobody would seriously argue that a non-party should be subject to obligations without her consent. This is even more obviously the case with intergovernmental agreements. To suggest that such agreements, without more, could create obligations for third parties smacks of legislating by prerogative. The point is illustrated, if it requires illustration, by Reference Re Anti-Inflation Act $t^{94}$ which also serves as an introduction to a remarkable series of Canadian cases dealing with the application of the anti-inflation guidelines to the public sector.

89. Burrard Power Co. v. R., [1911] A.C. 87 (P.C.).

90. In Australia the results of a transfer are even more far reaching for state laws of general application will not apply: Worthing v. Rowell and Muston Pty. Ltd. (1970), 123 C.L.R. 89. The reverse is true in Canada of provincial laws: Construction Montcalm v. Minimum Wage Commission, [1979] 1 S.C.R. 754.

9. A.G. Canada v. Higbie, [1945] S.C.R. 385. The majority of the court was of the view that a transfer could be effected by order in council alone. As a matter of law this was probably correct but as a matter of policy Rand J.'s view (at 433) (and that of a majority of the Court of Appeal) that legislative sanction was required seems preferable. Rand $\mathrm{J}$. was still able to concur in the result. Western Counties Ry. Co. v. Windsor and Annapolis Ry. Co. (1882), 7 App. Cas. 178 at 187 (P.C.); Higbie, ibid. esp. per Rand J. at 436.

93. See Dunstan v. Hell's Gate Enterprises Ltd. (1985), 22 D.L.R. (4th) 568 at 594, rev'd on the facts (1987), 45 D.L.R. (4th) 677 (B.C.C.A.): "The public rights which existed when the province passed the Railway Belt legislation were and are perpetual and cannot be extinguished except by proper legal authority. A grant by the Crown will not suffice; still less would the mere transfer from the Crown in right of the province to the Crown in right of the Dominion do so." 
The case is best known for its consideration of the peace, order and good government power of the federal parliament but the court was also invited to consider the validity and effect of an agreement between the governments of Canada and Ontario. Under the federal Anti-Inflation Act the federal government had elected, in the first instance, not to make the Act and its guidelines binding upon provincial government employees. However, the Act did provide that the regime might be extended to such employees by one of two different types of agreement. Under s. 4(3) of the Act a province might elect simply to apply the federal scheme. Under s. 4(4) a province might elect to operate its own scheme. Ontario took the first option. Section 4(3) provided, quite infelicitously, that:

The Minister may, with the approval of the Governor in Council, enter into an agreement with the government of a province providing for the application of this Act and the guidelines to [paraphrasing, Her Majesty and agents of the Province] ... and where any such agreement is entered into, this act is binding in accordance with the terms of the agreement and the guidelines apply in accordance with the terms thereof with effect on and after the day on and after which the guidelines apply, by virtue of the operation of this Act, with respect to Her Majesty in right of Canada.

The agreement between Ontario and Canada was executed on behalf of Canada by the Minister of Finance properly authorized by order in council. On behalf of Ontario the agreement was executed by the Treasurer and Minister for Economics and Intergovernmental Affairs relying upon a provincial order in council but no provincial statute. This raised two issues for the court: did the provincial executive have the capacity to conclude the agreement and, if so, could such an agreement bind the public sector? On the first point the court, speaking through Laskin C.J.C., did not take issue with the submissions of the province that it had a common law capacity to enter into agreements through the executive in the absence of a statutory restriction and there was no such restriction here. That however, as Laskin pointedly remarked, "does not answer the question of authority to effect changes in Ontario law through such agreements." 19

The fact that the Crown can contract carries the matter no farther than that the contract may be binding upon it or that it may sue the other contracting party on the contract. What we have here is not a contract in this sense at all, but an agreement to have centain legislative enactments become operative as provincial law. $\%$

In effect what the province was trying to do was legislate through the prerogative and that was no longer permissible.

An alternative possibility was to construe the federal legislation as being conditional legislation which would be triggered by the existence of an agreement which met its terms. On this view the operative legislation would very clearly be federal. Although the court would have upheld the validity of that legislation, Laskin C.J.C. was unable to construe it in this way. Critical to that finding was the specific language of s. 4(3) which

9. $\quad$ lbid. at 504 .
\%. $\quad$ lbid. 
contemplated that once an agreement had been negotiated the guidelines would take effect not in accordance with their terms but in accordance with the terms of the agreement; it seems to have been that distinction that made provincial legislation requisite. Certainly, a mere agreement could not affect the rights of third parties.

It is one thing for the Crown in right of a Province to contract for itself; it is a completely different thing for it to contract for the application to its inhabitants, and to labour organizations in the Province, of laws to govern their operations and relations without statutory authority to that end. This would be, in effect, to legislate in the guise of a contract. The terms of the present agreement, at their narrowest, embrace more than what the Crown can bring under contractual obligation of its own authority. ${ }^{97}$

This case is obviously sound insofar as it properly limits the power of the executive to legislate. The executive can affect the rights of third parties only with appropriately framed legislation. The case offers little guidance as to the form that such legislation might take but it does suggest that the authority to affect third parties (as opposed to the authority to enter into the agreement) may be found in either federal or provincial legislation provided that the legislation relied upon is constitutionally valid.

\section{AGREEMENTS WHICH ARE STATUTORILY AUTHORIZED}

\section{Introduction}

The result in the Anti-Inflation Reference invites the question what form of statutory approval of an agreement will suffice to bind third parties or, in other words, what form of statutory authorization or approval will allow us to conclude that an agreement has changed the law. ${ }^{98}$ The statutory endorsement of contractual arrangements has long been a feature of parliamentary systems. It was common in England during the nineteenth century in the context of railway and canal agreements and enclosures and is closely associated with the history of private acts. Extensive use has also been made of this technique in Canada for railways. In more modern times statutory endorsements are a common feature of state resource agreements in Australia and to a lesser extent in Canada, especially Newfoundland.

Much of the case law on these arrangements is of interest in the context of intergovernmental agreements which are approved by statute, a point that the High Court recognized in Sankey v. Whitlam. ${ }^{99}$ That body of case law has also been the subject of significant commentary in Australia. Especially notable is the work of Leigh Warnick in

9. Ibid. at 506 .

98. Framed in this way there are also fairly obvious analogies with the problem of incorporating international treaty law into domestic law. The general rule in Canada and Australia is the same as in England that a treaty is not self-executing and must be incorporated into domestic law in some way: Francis v. R., [1956] S.C.R. 618, Crawford and Edeson, supra, note 59. D.P. O'Connell, International Law, 2d ed. (London: Stevens, 1970) states at 61 that "It is rare for the text of a treaty to be given the force of law by direct legislation of parliament..." See Republic of Italy v. Hambros Bank Ltd., [1950] 1 Ch. 314, and see discussion in note 150, infra. 
a series of three articles on the subject. ${ }^{100}$ Mr. Warnick has identified at least eight alternative statutory endorsement formulas used in Australia but for our purposes, because of our interest in the effect of agreements on third parties, the analysis can be simplified. ${ }^{101}$

A fourfold classification will suffice for our purposes, but my fourth category has no counterpart in the state franchise agreements discussed by Mr. Warnick. First, there is statutory language which merely resolves any doubts that there might be as to the validity of, or authority to enter into, the agreement (e.g. the agreement is approved or execution of the agreement is authorized). Second, the ratifying language may have the effect of transforming a contractual arrangement into an arrangement that imposes statutory duties (e.g. the agreement is approved and all government officials are required/empowered to take all necessary acts to fulfil its terms). Third, the language may be such that the arrangement has the effect of a statute (e.g. the agreement takes effect as if enacted in this act.) Finally, there is an important category of agreements which clearly contemplate legislation but which are not themselves approved, ratified or given the force of law by legislation. Rather, they represent an agreement or arrangement about the scope of each government's legislative action and perhaps are nothing more than a set of instructions for the parliamentary draftsperson. Of these categories only the second and third are likely to have any consequences for third parties. In the case of the fourth category third parties will be dramatically affected, but by the legislation rather than the agreement.

\section{Statutory Approval for the Agreement}

\section{(a) Introduction}

Appropriate language to deal with this problem may be general or specific and prospective or retrospective. An example of general prospective language is found in $\mathbf{s}$. 7 of the Department of the Environment Act and quoted above in the Saskatchewan Water Corporation Case. Specific prospective language takes the form of an authorization for a Minister to enter into an agreement substantially as scheduled to the Act. For example, the States Grants Fruit Growing Reconstruction Act, 1972 (Cwth) provides that "The execution on behalf of the Commonwealth, of an agreement between the Commonwealth

100. L. Warnick, "State Agreements - The Legal Effect of Statutory Endorsement" (1982) 4 (1) A.M.P.L.J. 1, "The Roxby Downs Indenture" (1983) AMPLA Yb. 33 and "State Agreements" (1988) 62 A.L.J. 878.

101. Unfortunately Warnick was not immediately concemed with the question of third parties. It became of interest to him later because of the unreported decision in Margetts v. Campbell Foulkes, Supreme Court of Western Australia, Full Court, 29 November 1979, discussed in P.W. Johnston and R.S. French, "Environmental Law in a Commonwealth-States Context" (1980) 2:2 A.M.P.L.J. 77 at 86-87. Briefly, an alumina refinery operation was intermpted by radical environmentalists who were charged under s. 67 of the Police Act. The issue was whether the company was authorized to do something under a "law of the state", the agreement having been ratified but not given the force of law. The court didn't have to decide the question in the end but Warnick suggests that the appellant's defence was "quite correct" (i.e. the alumina operation was not conducted under the law of the state) (1988) 62 A.L.J. 878 at 896 . Warnick also notes at 897 that a company may be concerned about its security of title and third party staking claims. 
and all or any of the States substantially in accordance with the form set out in the Schedule to this Act is approved." ${ }^{102}$ Neither formulation changes the juridical status of the agreement although both provide a test for validity in that failure to comply with the terms of the authorization may render the agreement unenforceable as the Saskatchewan Water Corporation Case illustrates. Because the approval is purely prospective there is some suggestion that any agreement must still comply with all other legal requirements. ${ }^{103}$ Retrospective approval will usually take the form of legislative ratification of an executed agreement scheduled to the Act. For example, the Coal Loading Works Agreement (New South Wales) Act, 1961. (Cwth) provides that "The Agreement, a copy of which is set out in the Schedule to this Act is approved." The agreement may be expressed to be of no force until ratified by both parliaments. This formulation too cannot be considered to have changed the status of the agreement. Any of these retrospective formulations, however, will settle doubts that there might have been about authority to enter into the agreement and will cure some deficiencies in the agreement. $^{104}$

\section{(b) Canadian Cases}

In considering the cases in this and the succeeding sections I have drawn examples from both intergovernmental agreements and private contracts that have been statutorily approved. Of these latter cases, agreements between governments and developers are the most useful because of their public law content. I think considerable care must be used with those cases which deal with statutory approval of a contract between purely private parties; a practice which at one time was quite common in public utility fields. Nevertheless, this concern should not be overestimated for the courts, by and large, have used the authorities interchangeably.

One of the earliest Canadian cases on the effect of "approving" statutory language is Western Counties Ry. Co. v. Windsor and Annapolis Ry. Co. ${ }^{105}$ The issue in the case was whether or not third party rights had survived the statutory transfer of a railway. The critical language in the statute stated that the agreements scheduled to the act "and all the matters and things therein contained, are hereby approved and declared to be as effectual to all intents and purposes as if the said agreements had been entered into in pursuance of sufficient authority in that behalf given before the adoption of such agreements by Act of the Parliament of Canada." Despite its grandiloquence, that, as the Privy Council confirmed, was nothing more than the language of retrospective approval, which was no more effective to defeat third party rights than prospective approval. "There is," said their lordships, "a great difference between giving authority to make an agreement and

See also Tasmania Native Forestry Agreement Act, 1980 (Cwlth, No. 97 of 1980), Tasmania Agreement (Launceston Precision Tool Annexe) Act, 1980 (Cwlth, No. 98 of 1980), Western Australia Agreement (Ord River Irrigation) Act, 1980 (Cwth, No. 99 of 1980). All three agreements "authorize" the execution of an agreement essentially in the form appended to the Act.

104. Ibid. and Manchester Ship Canal Co. v. Manchester Racecourse Co., [1901] 2 Ch. 37, rule against perpetuities doesn't apply, accord Windsor v. Detroit and Windsor Subway Co. (1988), 3 R.P.R. (2d) 152 (Ont. C.A.), aff'd (1990), 12 R.P.R. (2d) 244.

105. (1882), 7 App. Cas. 178 (P.C.). 
authorizing it to be made and forthwith carried out so as to override and destroy all private rights that may stand in its way."106 Earlier the court had enunciated the governing rule of construction: "in order to take away the right it is not sufficient to show that the thing sanctioned by the Act, if done, will of sheer physical necessity put an end to the right, it must also be shewn that the Legislature have authorized the thing to be done at all events, and irrespective of its possible interference with existing rights."107

Some care must be taken with this dictum for it must be taken to apply to what are properly called Private Acts ${ }^{108}$ and one would not expect an intergovernmental agreement to fall into this category. Nevertheless, the case establishes an appropriate principle and one which was certainly referred to with approval by the Supreme Court of Canada in the leading Canadian case on this form of statutory language in the context of intergovernmental agreements: Re Manitoba Government Employees Association and Government of Manitoba. ${ }^{109}$

This case is the second of the anti-inflation cases. The provincial government wished to apply the guidelines to the public sector but did not pass specific implementing legislation. It relied instead upon s. 16 of the Manitoba Executive Government Organization Act ${ }^{110}$ and s. 4(3) of the federal Anti-Inflation Act. ${ }^{111}$ Section 16 of the Manitoba act was a basket provision providing that the Lieutenant Governor in Council could authorize a minister to enter into an agreement with the Government of Canada "for any benefit or purposes of the residents of Manitoba or any part thereof." We have already quoted s. 4(3) of the federal act above. The agreement itself, which was further authorized by provincial order in council, provided that "the federal act and the national guidelines shall apply to the provincial public sector."

Ibid. at 190.

Ibid. at 189.

See Craies on Statute Law at 566-68. The law on Private Acts is codified in Canada by the respective Interpretation Acts which state that no provision in a private act affects the rights of any person, except as therein mentioned or referred to: Canada, R.S.C. 1985, c. I-21, s. 9; Ontario, R.S.O. 1980, c. 219, s. 12; Alberta, R.S.A. 1980, c. I-7, s. 8. Canadian Interpretation Acts do not assist on the question of what constitutes a private act. The practice in Australia is different. For example the Interpretation of Legislation Act of Victoria provides (s.4(1)(a)) that the rules of interpretation so adopted shall apply to all acts of the parliament of Victoria.

(1978), 79 D.L.R. (3d) 1. In A.G.B.C. v. A.G. Canada (1989), 42 B.C.L.R. (2d) 289, Esson C.J.B.C. stated that the provincial statute approving the railway belt settlement of 1883 not only had the force of constitutional law but also had statutory force even though the language was merely "confirmed and ratified" (Dominion) or "notified and adopted" (Province). His Lordship relied on Esquimault and Nanaimo Ry. v. Treat, [1919] 3 W.W.R. 356 (P.C.) for this proposition, but it does not provide full support for the argument in my view. Another recent case asserts that statutory ratification has a more profound effect than is generally supported by the authorities: Procureur Général du Québec v. Cree Regional Authority, unreported judgment of the F.C.A. May 14, 1991. The case deals with the James Bay and Northem Quebec Agreement to which Quebec and Canada are parties. The statutory language was "The Agreement is hereby approved, given effect and declared valid." As a land claim agreement it is also protected by s. 35 of the Constitution Act, 1982, the effect of which was not considered by the court.

S.M. 1970 , c. 17.

S.C. $1974-75-76$, c. 75. 
The legal effect of the agreement was then challenged by the Government Employees Association on behalf of members who had a collective agreement which had been purportedly overridden by the federal anti-inflation administrator. The federal-provincial agreement was entered into after the collective agreement, and the Manitoba Executive Government Organization Act was passed before the Manitoba Labour Relations Act, pursuant to which the collective agreement had been negotiated.

That concatenation of circumstances proved fatal to those contending for the legal bindingness of the agreement on third parties, for it created four hurdles. First, s. 16 had to authorize the negotiation of the agreement; second, it had to confer the status of law upon the results; third, it had to allow the agreement to prevail over inconsistent and more detailed subsequent legislation; and finally, it had to allow the agreement retrospective effect. This was altogether too much to hope for from the language of s. 16. As Mr. Justice Ritchie stated for the majority: ${ }^{112}$

In my opinion s. 16 does no more than authorize the making of agreements as therein specified but it is lacking in any provision that such agreements once entered into will be effective to suspend the operation of other provincial legislation or constitute legislation binding on employees in the [provincial] public sector ... If the section is to be read as giving legislative force to all agreements entered into under the authority of an Order in Council on the ground that the Executive deems such an agreement to be "for the benefit or purposes of the residents of Manitoba," then this would appear to me to constitute a delegation of legislative power amounting to an abdication by the Legislature of its ultimate authority to pass laws "for the benefit or purposes of the residents of Manitoba."

Furthermore, there was nothing in s. 16 which expressly or by implication contemplated either a retroactive application or an interference with the vested rights of governmental employees. Consequently the majority found that the agreement had not changed the law of Manitoba.

In giving the majority judgment, Ritchie J. focused upon the Manitoba legislation. He scarcely found it necessary to refer to s. 4(3) of the Anti-Inflation Act because he viewed the Anti-Inflation Reference as having decided that s. 4(3) required provincial authorizing legislation in order for the public sector of the province to be bound, not as a matter of constitutional law, but simply as a matter of construction of the section.

Chief Justice Laskin's dissenting opinion (Martland, Judson, and Spence JJ. concurring) proceeded on rather different assumptions. It is clear from his judgment that Laskin himself had doubts as to the efficacy of s. 16 of the Manitoba legislation if that alone were to be relied upon to change the law of Manitoba. However, Laskin was of the view that s. 16 had to be read with s. 4(3) of the federal act, quoted above. In his view s. 4(3) made it plain that what was occurring was a federal exercise rather than a provincial exercise. The agreement governed the scope of the federal intervention and did not itself 
breathe vitality into the federal legislation which was operative of its own force. As Laskin stated in the last paragraph of his judgment: ${ }^{113}$

It is one thing to regard s. 16 as itself authorizing a change in provincial law by reason of an agreement authorized thereunder through which the change is made by incorporating into the agreement provisions of a federal statute to operate as provincial law. I would agree that in such a case the mere entry into an agreement cannot accomplish such a change because the agreement leads nowhere except back to its source which is s. 16. That, however, is not this case. It is another thing to view s. 16 as providing a legislative base for an agreement which becomes operative under federal law and which makes that law, as federal law, applicable in a Province to the extent provided in the agreement. That is this case and, in my opinion, s. 16 is apt for this purpose.

It is clear however that Laskin would not dissent from the basic proposition that only a statute validly drawn can change the law of the land and that a mere executive agreement is ineffective. To Laskin, however, this was no mere executive agreement because it incorporated a law which had independent validity. The provincial statute was adequate to change the scope of the federal statute's application. The agreement was an essential link in the argument because it laid out the details of the area of application much as a statutory instrument might.

Laskin's interpretation, although plausible, does seem inconsistent with his lordship's finding in the Reference case that the federal legislation was not conditional legislation brought into force by the requisite provincial action. ${ }^{114}$ Matters of consistency aside, however, Ritchie's interpretation still seems preferable. The agreement was purporting to change the economic and contractual rights of third parties retrospectively; we are entitled to insist that this be done only by the clearest possible statutory language.

The divergence in views of Laskin and Ritchie JJ. does however reinforce the point that it is necessary to examine the legislation of both levels of government (assuming both are valid) in order to determine whether a non-party will be affected by the agreement. The case also bears the interpretation that an agreement which has merely been approved by legislation remains essentially a matter of private rather than public law.

\footnotetext{
113. Ibid. at 8 .

114. That decision was ambiguous as to whether or not the guidelines would become operative as federal or provincial law. On the one hand Laskin J. seems to suggest that it would be a federal operation but these remarks are made at [1976] 2 S.C.R. 373 at 431 in the context of the conditional legislation argument which failed. On the other hand there seems to be a suggestion at 432 to 433 that if the guidelines were to operate as other than federal conditional legislation then the exercise would be a provincial one. The judgment is not clear on this point.
} 


\section{(c) Australian Cases ${ }^{115}$}

The effect of statutory approval of an agreement on third parties has not been raised in such black and white terms in the Australian case law, but one can say that the High Court in particular has been extremely reluctant to accord legal status to intergovernmental agreements or to concede that they might have any effect on third parties. ${ }^{116}$ It has been similarly reluctant to give the agreements themselves any public law status or objective validity. At the same time the court has consistently emphasized the pre-eminence of the approving or implementing legislation.

The leading case is Sankey v. Whitlam. ${ }^{117}$ Care must be taken in applying this case in the present context because it relates to the constitutionally protected Financial Agreement ${ }^{118}$ and also because of the highly charged political circumstances in which it arose. In addition to the protection afforded by s. 105A of the Constitution, the agreements were also approved by Commonwealth and state legislation. ${ }^{119}$ Among other things the agreement established the Australian Loan Council and provided that monies should not be borrowed by the Commonwealth or any state except in accordance with the agreement.

115. Readers familiar with the case law will note the omission in the discussion at this point of Ansett Transport Industries (Operations) Pty. Ltd. v. Commonwealth (1977), 139 C.L.R. 54. The rationale for the omission is that while the case deals with a statute which merely approves the agreement (and is consistent with the cases discussed in the text) the most interesting portion of the judgments deal with what additional statutory language would be required to give an agreement some objective effect. Consequently the case is discussed in the following section.

116. This can be seen in the soldier settlement cases referred to supra, note 71 but perhaps the best known case is South Australia v. Commonwealth (1962), 108 C.L.R. 130, the Railway Gauge Case.

117. (1978), 142 C.L.R. 1 and for comment on the background see Saunders, supra, note 18. For a case on an agreement which was merely "ratified" but was of an equally unique nature see State Bank of New South Wales v. Commonwealth Savings Bank of Australia (1984), 60 A.L.R. 73; there the question was whether the agreement was terminable at will. It was held not to be even though it was both a political and a legal arrangement.

118. Section 105A of the Australian Constitution provides, so far as is relevant that:

(1.) The Commonwealth may make agreements with the States with respect to the public debts of the States, ...

(2.) The Parliament may make laws for validating any such agreement made before the commencement of this section.

(3.) The parliament may make laws for the carrying out by the parties thereto of any such agreement.

(4.) Any such agreement may be varied or rescinded by the parties thereto.

(5.) Every such agreement and any such variation thereof shall be binding upon the Commonwealth and the States parties thereto notwithstanding anything contained in this Constitution or the Constitution of the several States or in any law of the Parliament of the Commonwealth or of any State.

119. The Commonwealth legislation just "approved" the agreement. Some of the state legislation was considerably more far reaching, notably Victoria's, Act No. 3554. 
Earlier cases on the Financial Agreement had acknowledged the fundamental nature of the arrangement. Thus in the Garnishee Case ${ }^{120}$ the High Court upheld Commonwealth legislation designed to enforce the terms of the agreement against a recalcitrant state, and in the State Banking Case ${ }^{121}$ and the Bank Nationalization Case ${ }^{122}$ the High Court seemed to accept, in principle, that the agreement might act as a limitation on legislative power. A very different question arose in Sankey v. Whitlam. Sankey laid a private information against Whitlam, a former prime minister, and former members of his cabinet alleging a conspiracy to effect a purpose that was unlawful under "a law of the Commonwealth" and therefore an offence under the Commonwealth Crimes Act.

The particular breach alleged was a breach of the Financial Agreement requirement that all Commonwealth borrowing be in accordance with the agreement. A conspiracy to breach the Constitution Alteration (State Debts) Act and the Financial Agreement Act was also alleged. A separate charge alleged a further conspiracy to deceive the Governor General into believing that the loans in question were temporary when they were in fact not so, all in breach of the agreement and the above statutes.

The real issue for our purposes was the question of whether or not the provisions of the loan agreement could be said to be a "law of the Commonwealth" within the meaning of the Crimes Act. Thus the court raised in a very direct way the effect of the agreement on third parties: was it an objective public law, creating obligations for third parties, or was it merely a contract?

The court answered firmly and unequivocally that it was the latter, although acknowledging that the Commonwealth could have used its powers under s. 105A(3) to make a breach of the agreement an offence. ${ }^{123}$ With the exception of Jacobs $\mathrm{J}^{124}$ all the members of the court gave detailed and separate consideration to the status of the agreement and the various statutes designed to validate or ratify it.

The agreement itself seems to have caused the court the greatest difficulty, perhaps because of the earlier decisions which had described it as part of the "organic law of the Commonwealth,"125 fundamental law"126 and operating with "obligatory force."127 Nevertheless all members of the court who addressed the matter thought that the agreement was not a law of the Commonwealth. Gibbs and Stephen JJ. devoted most attention to the problem. In Gibbs' view: ${ }^{128}$

(1932), 46 C.L.R. 155.

(1947), 74 C.L.R. 31.

(1948), 76 C.L.R. 1.

Although the High Court was singularly unimpressed with Sankey's arguments, they were much more convincing to the New South Wales Court of Appeal which considered them in a preliminary way on an application for prohibition to issue against the criminal proceedings: Connor v. Sankey, [1976] 28 F.L.R. 267, esp. per Street C.J.

Supra, note 117 at 102 , Jacobs J. merely stated that no offence was disclosed.

Garnishee Case (1932), 46 C.L.R. 155 at 186, per Starke J.

Ibid. at 228-29, per McTiernan J.

Ibid. at 177, per Rich and Dixon JJ.

Supra, note 117 at 30 . See also Stephen J. at 74. 
It is true to say that the Financial Agreement has the force of law, even of an organic law, so far as the Commonwealth and the States are concemed. However it does not create rights in or impose duties on other persons; it is binding by s. 105A(5) only on the Commonwealth and the States. Notwithstanding s. 105A(5) I do not think it accurate to describe the Financial Agreement as a law. It is in truth sui generis...even if it could be described as a law, it is not a law of the Commonwealth, because it is not made by or under the authority of the Parliament of the Commonwealth.

There was also consensus among the bench as to the effect of the validating and approving statutes of the Commonwealth: ${ }^{129}$ they were not aptly framed to transform something that was not a law of the Commonwealth into such a law. The court discerned in the case law $^{130}$ a distinction between statutes that merely approved or validated an agreement and statutes that incorporated the agreement into the text of the statute and gave each clause the effect of a statutory provision. In the case of the approving statutes the members of the court were of the view that they merely served the function of fulfilling a condition precedent to the validity of the agreement. ${ }^{131}$ In a similar vein, a validating act was merely concerned retrospectively to confer upon the agreement the constitutional protection accorded by s. 105A. ${ }^{132}$

As to the Constitution and the Constitutional Amendment, these two potential sources of objective vitality were readily dismissed by the court. The Constitution itself was more than a law of the Commonwealth and the same was true of any amendment, a point which was textually confirmed by the fact that an amendment does not include the term "Act" in its title ${ }^{133}$ and by the reference to the electors in the enacting clause. In addition, s. $105 \mathrm{~A}$ never changed the status of the agreement; it merely left it as a contract binding the parties. ${ }^{134}$

Sankey was followed by Mason J.'s dismissal of an application for an interlocutory injunction in Tasmanian Wilderness Society Inc. v. Fraser. ${ }^{135}$ The plaintiffs sought an injunction against the prime minister and federal treasurer who were to attend an Australian Loan Council meeting to restrain them from voting in favour of borrowing to be used by the state electricity agency to dam the Franklin. The plaintiff was relying upon the federal Heritage Act and the Environmental Protection Act but, to make its case, had to establish that the Loan Council was an "authority of the Commonwealth" "established by or appointed under the laws of the Commonwealth." Mason J. rejected this contention, holding that the ALC was established by contract and not by statute. In

Because of the particular issue at stake the court did not find it necessary to consider the effect of the state legislation.

The cases particularly relied on were $R$. v. Midland Railway Co. (1987), 19 Q.B.D. 540, Manchester Ship Canal Co. v. Manchester Racecourse Co., [1901] 2 Ch. 37, Pyx Granite Co. v. Minister of Housing and Local Government, [1960] A.C. 260, Caledonian Railway Co. v. Greenock and Wemyss Bay Railway Co. (1874), L.R. 2 Sc. \& Div. 347.

Members of the court referred here with approval to Placer Development Ltd. v. Commonwealth (1969), 121 C.L.R. 353.

Supra, note 117, esp. per Mason J. at 91 and Stephen J. at 77.

Ibid. per Stephen J. at 75.

Ibid. per Mason J. at 90.

(1982), 153 C.L.R. 270. 
reaching this conclusion Mason seems to have considered that the point was established by Sankey v. Whitlam.

Dicta in other Australian decisions support this rather minimalist view of the effect of statutory approval language in intergovernmental agreements. In Magennis's Case, ${ }^{136}$ for example, the Commonwealth legislation "hereby authorized" the execution of agreements substantially in the form appended while the state legislation "approved and ratified" the agreement. The majority of the court found the agreement void for constitutional reasons but Dixon J., dissenting, found the agreement to be of marginal relevance to a case which should have been decided on the basis of the validity of the state legislation alone. "If the agreement is examined it will be found that there are not a few clauses which depend on, or provide for, agreed action by State and Commonwealth, and the general tenor of the document suggests rather an arrangement between two governments settling the broad outlines of an administrative and financial scheme than a definitive contract enforceable at law." ${ }^{137}$ By the time of Gilbert v. Western Australia ${ }^{138}$ in 1961, Dixon had brought the court around to his point of view. In that case the court described the agreement as ${ }^{139}$ "an agreement between governments recording arrangements of a political and administrative character." The court went on to quote the passage from Magennis with approval and then stated that "[w]hatever was its legal nature as between Commonwealth and State, it is quite clear that, of itself, it created no private rights. A settler got no rights directly from it. His rights arose from the transaction that the State entered into with him." ${ }^{140}$

At about the same time the court was also deciding the Railway Gauge Standardization Case. $^{141}$ In that case the relevant Commonwealth legislation provided that the execution of the agreement was authorized and was deemed to have been approved by Parliament. The state legislation simply approved the agreement and empowered certain officials to do all acts necessary to implement the agreement. The court refused to enforce the agreement on two grounds: first, that the agreement was merely an agreement to agree, and second, that there was no intention to create legal relations. Statutory approval does not seem to have been relevant to this question ${ }^{142}$ and indeed was only alluded to by two members of the court in connection with an argument that the Commonwealth had

(1949), 80 C.L.R. 382.

lbid. at 409 . McTiernan J. at 413 agreed with Dixon J. on this point.

(1962), 107 C.L.R. 494.

Ibid. at 503.

Ibid.

South Australia v. Commonwealth (1962), 108 C.L.R. 130.

142. But see Windeyer J. dissenting in Placer Development Ltd. v. Commonwealth, supra, note 131 at 366. A Commonwealth statute had "approved" an agreement with the company which provided for a rebate in the event that customs duties were imposed. The issue before the court was primarily one of intention to create legal relations. Windeyer J. stated that statutory approval "disposes... of any idea that the Agreement was not intended by the parties to create a relationship giving rise to obligations enforceable by law." 
repudiated the agreement. ${ }^{143}$ Two members of the court also referred with approval to the passage quoted from Magennis above. ${ }^{144}$

As already indicated, these Australian cases do not deal directly with the issue of the effect of agreements on third parties, but they are indicative of a general approach which suggests that the agreements are matters of private law of interest only to the parties or are only political arrangements. On either view third parties have only a limited role to play. If the agreements are merely political arrangements the public role is limited to the ballot box, which provides a particularly hollow form of accountability where there may be two governments to hold responsible. On the other hand the more the agreements are viewed as private law arrangements, the easier it is for the courts to deny the public a role in their implementation. The agreements themselves do not constitute law and it presumably follows that decisions made pursuant to such agreements are not statutory decisions amenable to judicial review. ${ }^{145}$

\section{Statutory Approval and the Imposition of Statutory Duties}

\section{(a) Introduction}

In the second category of arrangements the statutory language goes beyond that of approval or ratification without adopting the "and the agreement shall take effect as if enacted in this Act" formula or its equivalents. In particular the statute may authorize or require government officials to take all steps necessary to give effect to the agreement. This formula is particularly common in modern resource franchise agreements, ${ }^{146}$ but what effect does it have? Mr. Warnick takes the view that it is almost as efficacious as the "as if enacted" formula ${ }^{147}$ but I have some doubts as to whether it can be taken this far, at least in the present context where the issue in relation to third parties must be "has the agreement changed the law?" The primary authority relied upon for the proposition that the contractual obligations become statutory duties is Caledonian Ry. Co. v. Greenock and Wemyss Bay Ry. Co. ${ }^{148}$ but that decision concerned an agreement and a dispute between two private companies and has nothing to say on the problems of fettering executive discretion or amending existing statutory provisions. ${ }^{149}$

Supra, note 141, per Windeyer J. at 152: "as the making of the Agreement was authorized by statutes of the Commonwealth and the States repudiation is a difficult concept to apply to it." Dixon C.J. at 147: "No such case, however, has been made or could be made upon the agreement confirmed as it is by statute on both sides."

144. Ibid. per Taylor J. at 149 and Owen J. at 157.

145. This issue has not arisen directly as far as I am aware in the context of an Australian intergovernmental agreement but it has come up in relation to the statutory approval of an agreement between govemment and private parties: Dept. of Aviation v. Ansett Transport Industries Ltd. (1987), 72 A.L.R. 188. Warnick, (1982) 62 A.L.J. 878 at 887, notably in South Australia.

147. (1982) 4 (1) A.M.P.L.J. 1 at 19. He also obtains some support from E. Campbell, "Legislative Approval of Government Contracts" (1972) 46 A.L.J. 217 at 218.

148. (1874), L.R. 2 Sc. 7 Div. 347.

149. Wamick seems to concede this in his later A.L.J. article but still describes provisions which modify specific provisions of the existing regime as overkill: supra, note 146 at 887-888. 
Examples of this kind of statutory formulation, so common in resource franchise agreements, are rare in the context of intergovernmental agreements. ${ }^{150}$ The South Australian legislation in the Railway Gauge Case probably fits into this general category, but the most interesting examples relate once again to the Canadian cases on provincial government attempts to apply the anti-inflation guidelines to the public sector.

\section{(b) Canadian Cases}

Although at least one province adopted an "as if enacted" formulation for the antiinflation agreements, ${ }^{151}$ both British Columbia and New Brunswick invited further litigation by using considerably more complex formulae. The British Columbia legislation ${ }^{152}$ provided that:

The minister may, on behalf of the Government and with the approval of the Lieutenant-Govemor in Council, enter into agreements

(a) with Canada respecting the application of the Anti-Inflation Act (Canada), the regulations and Federal guidelines in the Province, and the manner and extent to which .... [they] shall apply to the prices of commodities or services and the compensation of employees in the Provincial public sector, and

(b) with Canada, or any other province or state, or with their departments or agencies, as the minister considers necessary or advisable for the purpose of carrying out any of his powers and duties under this Act, or for exchanging information or statistics, or for any other joint action.

The Act also conferred a very broad regulation-making power upon the Lieutenant Governor in Council. At first sight the legislation would not seem to go very far beyond that which was ruled ineffective in the Manitoba Government Employees Case. Nevertheless, the provincial authorities were undoubtedly strengthened in their position by some delphic dicta in that case. At the end of his judgment Ritchie J. stated that unlike the Manitoba legislation ${ }^{153}$ "there are cases of which British Columbia is an example, where the legislative authority is so clearly spelled out as to give rise to no difficulty." His lordship then quoted s. 5(a) and continued: ${ }^{154}$ "The glaring difference between this type of legislation and the [Manitoba Act] ... will be at once apparent." It obviously wasn't apparent to everybody, for the Ritchie view was challenged in a case

See Indian Affairs Settlement Act, S.B.C. 1919, c.32, ss. 2 \& 3. An analogous formulation has been used by the Canadian parliament for the purposes of implementing international treaties in domestic law. The International Boundary Waters Treaty Act, R.S.C. 1985, c.I-17, provides: s. 2 "The treaty... and the protocol...in the schedule, are hereby confirmed and sanctioned." s. 3 "The laws of Canada and of the provinces are hereby amended and altered so as to permit, authorize and sanction the performance of the obligations undertaken by His Majesty in and under the treaty, and so as to sanction, confer and impose the various rights, duties and disabilities intended by the treaty to be conferred or imposed or to exist within Canada." See Burnell v. International Joint Commission, [1977] 1 F.C. 269.

151. See infra, note 172 .

152. Anti-Inflation Measures Act, S.B.C. 1976, c. 1, s. 5.

153. (1978), 79 D.L.R. (3d) I at 17 (S.C.C.).

154. Ibid. at 17. 
which was first argued before judgment in the Manitoba case was available: $R e$ British Columbia Teachers' Federation and Board of School Trustees of School District No. 41 (Burnaby). ${ }^{155}$

The facts were similar to those of the Manitoba case. Teacher salaries were rolled back by the Anti-Inflation Board and the teachers argued that this had been done without lawful justification. The province and Canada had entered into an agreement in June 1976 to apply the guidelines to the public sector effective from 14 October 1975. Unfortunately, Nemetz C.J.S.C. did little more than quote Ritchie's dicta in support of his view that the language was clear enough to affect private rights and to affect them retrospectively even though the Act merely stated that the agreement could deal with the "manner and extent" of the application of federal rules. ${ }^{156}$ The court also rejected a submission to the effect that the agreement was invalid because it was a regulation and had never been filed as required by the Regulations Act. Again the reasoning on this point is weak and ignores the strong policy argument for insisting upon publication of instruments intended to affect the rights of citizens.

A particularly clear instance of this second category of statutory ratification which illustrates the importance of the particular language used is Ottawa Electric Railway Company v. City of Ottawa. ${ }^{157}$ The city and the company had entered into an agreement relating to the company's service. Subsequently, the agreement was approved by both provincial and federal legislation although the court ${ }^{158}$ was of the view that it need only be concerned with the federal act. The first two sections of the legislation were relevant:

The agreement set out in the Schedule to this Act ... is ratified and confirmed, and the parties thereto are hereby empowered and authorized to carry out their respective obligations and to exercise their respective privileges thereunder.

Notwithstanding the provisions of The Railway Act ... the rates of fares ... as established by the said agreement, shall not be altered before the thirteenth day of August, 1928, either by the parties thereto or by the Board of Railway Commissioners for Canada, and thereafter any alteration in such fares shall be governed by the terms and conditions of the said agreement.

The agreement provided that before any application was made by the city to the board to decrease the company's fares, the company would be entitled to notice in particular form. The city had made an application to the board which did not comply precisely with this procedure. The question therefore arose as to what was the effect of this noncompliance, a question which raised for some members the issue of whether the agreement should be construed as a statutory enactment or as a contract.

(1977), 83 D.L.R. (3d) 190 (B.C.S.C.).

A similar conclusion was reached by Stevenson J. in New Brunswick Public Employees Association v. Province of New Brunswick (1977), 20 N.B.R. (2d) 62. [1945] S.C.R. 105.

Ibid. per Rinfret C.J. at 112, who gave no explanation for this conclusion. 
Justices Rand and Kerwin were unequivocal. In Kerwin's view the first section was merely concerned with ratification and confirmation. But the second section led "to the conclusion that something more than mere approval of the agreement is accomplished and that in fact the agreement should be construed as a statutory enactment." ${ }^{\text {159 }}$ Rinfret C.J. (Taschereau J. concurring) thought that the primary purpose of the enactment was confirmation and validation, achieved by $\mathrm{s} .1$ of the Act which, they noted, did not make the agreement part of the Act. ${ }^{160}$ However, they also conceded that the direction to the board and the effect on rates charged to the public went beyond that purpose. Kellock J. found it unnecessary to pass an opinion on this point.

It is quite clear from the judgments that it was the second section and not the first, even with its empowerment clause, that was critical to the characterization of the agreement as something more than a mere contract. There was a recognition that $\mathrm{s} .1$ alone could not have been relied upon to establish an inconsistency and thereby prevail over the Railway Act; for this purpose, a specific provision was required.

\section{(c) Australian Cases}

The most sophisticated discussion of these problems is found in the Ansett ${ }^{161}$ decision of the High Court in the context of the two airlines policy which Australia followed for many years. The agreement in question was merely "approved" by Commonwealth legislation, but it is discussed here rather than in the earlier section because some members of the court (notably Mason J.) did consider at length what form of statutory approval would be requisite to change the law. The agreement in question was executed by the Prime Minister for the Commonwealth and by the Australian National Airlines Commission, Ansett Transportation Industries Ltd. and Australian National Airlines Pty. Ltd. It was approved by Commonwealth legislation which provided for each of the scheduled agreements that "the agreement ... is approved."162 It was therefore not an intergovernmental agreement but nevertheless it was of high political importance and there are strong similarities between this sort of agreement and intergovernmental arrangements. ${ }^{163}$ The particular issue before the court was whether or not the Commonwealth had a duty not to issue import licences to a non-party because of the agreement. The plaintiffs sought declarations and injunctions to that effect.

The plaintiffs faced two major obstacles. First, the agreement did not specifically address itself to this question and thus they were forced to argue either that there was an implied covenant or that the Commonwealth would do nothing to prejudice its ability to fulfil the terms of the agreement. The second problem was that the power to issue import licences was actually vested in the Secretary of the Department of Transport under

159.

160.

161.

162.

163.

Ibid. at 122 and Rand J. at 126.

Ibid. at 117.

Supra, note 115.

Airlines Agreements Act, Cwth. 1952-73.

Tasmania was granted leave to intervene on the s. 92 issue which might have been raised by the agreement. Quaere whether standing might have been granted for the full range of issues given the "public" nature of the arrangement? 
customs regulations passed pursuant to the Customs Act. All in all this was a tall order, not least because it amounted to an argument that the agreement had substantially fettered Commonwealth executive discretion.

In the result only two members of the Court, Barwick C.J. and Aickin J., were prepared to imply a term of the type argued for. They were also of the view that legislative approval of the agreement pre-empted any issue as to an invalid fettering of discretion. ${ }^{164}$ Gibbs J. seemed to support the latter position. ${ }^{165}$

Justice Mason was much more careful on this point. ${ }^{166} \mathrm{He}$ clearly envisaged the possibility that some forms of statutory approval could "expressly or impliedly amend, for the purposes of the contract, the pre-existing law providing for the exercise of the discretion." 167 In such a case "the contracting party may be able to compel the government and the person in whom the discretion is vested, though it has been relevantly converted into a duty, to comply with the undertaking." ${ }^{168}$ Other forms of authorization, however, might not go so far. The authorizing statute may leave a statutory decision maker "with a discretion to arrive at some other result." Nevertheless the authorization will suffice to ensure that "there is no room for the notion that the undertaking is invalid on the ground that it is an anticipatory fetter on the exercise of a statutory discretion." 169 In such a case it may be possible to claim damages for breach of the contractual undertaking but it cannot be enforced specifically. Perhaps a way of capturing this distinction is to suggest that some forms of statutory authorization will actually change the law of the land (i.e. a public law effect) while others will merely overcome doubts about fettering of discretion and permit a contractual action (i.e. a private law effect).

The present case was much more limited than that presented by either of these possibilities: ${ }^{170}$

The existence of the statutory approval ... does not enlarge or narrow the ambit of the discretion which is conferred by the ... Regulations on the Secretary of the Department. Neither the statutes nor the

Supra, note 115, per Aickin J. at 113 and Barwick C.J. at 61.

lbid. at 62 .

Gibbs J. in general concurred with Mason J. subject to some equivocal comments on fettering, ibid. at 62. Murphy J.'s judgment on these points is not entirely clear but he does provide (at 85) a helpful characterization of the plaintiff's arguments as (1) a contention that the Customs Act and regulations had been impliedly amended by the statutory approval, alternatively, (2) that the Secretary was obliged by the Agreements to reject the licence. Like Mason J., Murphy J. was extremely reluctant to read in any such term.

lbid. at 77 .

Ibid. Mason J. is speaking here of specific performance but perhaps mandamus might be more appropriate? In Dept. of Aviation v. Ansett (1987), 72 A.L.R. 188, the Federal Court of Appeal held that a decision contemplated by the agreement when statutorily approved could be a decision "under an enactment" within the meaning of the Administrative Decisions Judicial Review Act. It should be noted that the agreement had been amended in a material way from that considered in the earlier case.

Supra, note 115 , at 77.

Ibid. at 77-78. See also Australian Airlines Commission and Ansett Transportation Industries Lid. v. Commonwealth (1986), 17 F.C.R. 445, Northrop J. attempts to apply the dicta of Mason J. 
agreements make any reference to that discretion. It is altogether too much to suggest that there is an implied amendment of the regulations brought about by an implied and unexpressed covenant in the agreements adopted and enacted sub silentio by the approving statutes. The statutory approvals in my opinion do no more than satisfy the condition which is contained in the various agreements ${ }^{17 !}$ and, accordingly, make the agreements contractually binding on the Commonwealth.

All of this was on the assumption that a covenant of the type contended for could be established but, on that point too, Mason J. found against the plaintiffs on the grounds that the executive should not lightly be taken to have fettered itself in this way.

In this portion of the paper we have been considering whether a statutory approval formulation which imposes statutory duties upon government officials can affect third parties by changing the law of the land. It should be noted that this question is considerably more specific than one which other commentators have considered: is the duty a contractual duty or a statutory duty? Consequently, it is hardly surprising that, for the most part, courts in both countries have demanded clear legislative language. The exceptions are the later Canadian cases on the anti-inflation guidelines, which must be considered as doubtful authority.

\section{Approval of the Agreement "As If Enacted in This Act."}

\section{(a) Introduction}

The "as if enacted in this Act" formula or some variation thereof is the strongest form of statutory approval available. It is commonly used in franchise agreements and other similar commercial arrangements. It has also been used in Canada for constitutionalized intergovernmental agreements such as the Terms of Union and the Natural Resources Transfer Agreements, and for other important intergovernmental agreements such as those in relation to Indian lands. ${ }^{172}$ So far as $I$ know it has not been used for intergovernmental agreements in Australia.

\section{(b) Canadian Cases}

Much of the Canadian case law deals with the constitutionalized agreements, but the effect of approval on a third party arose in a very straightforward non-constitutional case

171. Section 1 of the agreement provided that it was of no force or effect and not binding until approved by Parliament.

172. E.g. Ontario Indian Lands Agreement, 1924. Section 2 of the Ontario Act, S.O. 1924, c. 15, reads "The agreement between the Dominion of Canada and the Province of Ontario, in the terms set out in Schedule ' $\mathrm{A}$ ' hereto, shall be as binding on the Province of Ontario as if the provisions thereof had been set forth in an Act of this Legislature, and the Lieutenant-Govemor in Council is hereby authorized to carry out the provisions of the said agreement." Banff-Windermere Road Agreement Act, S.B.C. 1919, c. 5, esp. s. 3. The Prince Edward Island anti-inflation legislation (S.P.E.I. 1975, c. 63) authorized the execution of an agreement and then went on in s. 2 to provide that the resulting agreement was binding upon the provincial sector and "has the force and effect of an Act of the Legislature of this Province." 
in Canadian Northern Pacific Railway v. New Westminster Corporation. ${ }^{173}$ A contract between the company and the provincial Crown purported to provide the company with an exemption from provincial and municipal taxes for a number of years. The contract had then been approved by provincial legislation in the "as if enacted" form and one of the questions that now arose was whether the agreement bound the City of New Westminster. The Privy Council, after commenting that much of what had been promised in the act could not have been achieved without legislation, stated that the agreement ${ }^{174}$ "operates as if it were a clause in an Act of the provincial Legislature, and is binding on the city of Westminster with the force of such an Act."

The Canadian case law on the constitutionalized agreements has been discussed at length elsewhere. ${ }^{175}$ Much of it turns upon the fact that the "as if enacted" formulation actually refers to an Act of the Westminster Parliament and consequently that the agreement can act as a limitation on legislative power. ${ }^{176}$ It may be argued however that some of the cases simply turn upon the existence of statutory ratification rather than the constitutional level of the ratification. This may be particularly true of the Natural Resources Transfer Agreements which were approved not only by Imperial legislation but also by federal and provincial legislation. ${ }^{177}$

One case which falls into this category is Reference Re Timber Dues. ${ }^{178}$ Under the Transfer Agreements the provinces undertook to carry out the terms of any arrangements that the Dominion Crown might have entered into in relation to the public lands. The agreement did not explicitly extinguish the rights of the third parties (called "entrants" by the court in this case) against the Dominion Crown. Nevertheless, the Privy Council held that the statutory authorizations must have worked a statutory novation. The relevant passage in the judgment of the Privy Council merits quotation in full. ${ }^{179}$

It is clear that the agreement in itself in no way binds the entrant: he is not a party to it and so far his rights have not in any way been affected. Nor does the fact that the agreement has in each case been confirmed by the British North America Act, 1930, which enacts that these agreements shall have the force of law, necessarily change the position. The entrant is ... in the position of a creditor, and is not ... compellable to accept as his debtor any other person than the original debtor unless he so agrees. If he does so agree, there is a novation... [I]n the special circumstances of this case the statute of 1930 did effect such a novation.

[1917] A.C. 602 (P.C.). See also A.G. Newfoundland v. Churchill Falls (Labrador) Corporation (1985), 168 A.P.R. 91 (Nfld. C.A.), aff d by S.C.C., [1988] I S.C.R. 1085.

Ibid. at 604.

See article referred to supra, note 1.

See for example Spooner Oils Limited v. Turner Valley Gas Conservation Board, [1933] S.C.R. 629, $R$. v. Sutherland, [1980] 2 S.C.R. 451. Most of the cases, like Sutherland, deal with the Indian hunting clause of the agreements.

This led Lord Asquith to say that the agreements had "triple statutory force", A.G. Alberta v. West Canadian Collieries Lid., [1953] A.C. 453 at 455.

[1935] A.C. 184 (P.C.). See also A.G. Alberta v. Huggard Assets Ltd., [1953] A.C. 420 at 452-53 (P.C.).

Ibid. at 197-198. 
The court then referred to the fact that the lands had been transferred to the province which had in turn undertaken certain obligations before concluding that "[i]t follows that even vis-a-vis the entrant the obligation has by force of the law become the obligation of the Province. Thus there is effected by force of law what may be called a statutory novation."

These two cases therefore stand as authority for the proposition that the "as if enacted" formulation will change the rights of those persons against whom it is specifically directed and also of other persons by clear and necessary implication. There still remains in each case an important question of construction: did the legislature intend to bind a particular class of individuals or change a particular category of private rights?

\section{(c) Australian Cases}

Consistent with these observations, although again obiter, is the decision of the Privy Council in the Australian appeal of Peinkinna ${ }^{180}$ In Peinkinna the Director of Aboriginal and Islanders Advancement in the State of Queensland entered into an agreement with a number of mining companies. The agreement was scheduled to the Aurrukun Associates Agreement Act, 1975 which provided that the provisions of the agreement "were to have the force of law as though the agreement were an enactment of this Act." The plaintiffs, who were aboriginal residents of the reserve that would be affected by the mining operations, sought to argue that the Director was in breach of trust duties owed to them. The case ultimately reached the Privy Council which dismissed the claim. The main reasons given turned on principles of trust law. However, their lordships also considered the point of statutory endorsement, and while they were of the view that the language did not go so far as to give the agreement the force of law they did recognize the agreement as valid and subsisting and that the language precluded arguments of a breach of trust. ${ }^{181}$

\section{Agreements That Are Implemented by Statute}

We have already seen, insofar as third parties are concerned, that the existence of an intergovernmental agreement may be secondary in importance to the legislative backing that is given the agreement. Nevertheless, the agreement itself cannot be ignored. In this

Corporation of the Director of Aboriginal and Islanders Advancement v. Peinkinna (1978), 52 A.L.J.R. 286 (P.C.).

Unfortunately, the Committee failed to consider the argument that the plaintiffs had no standing to bring the action on the grounds that it should have been brought by the Attorney General in his capacity as guardian of charity. Two other Australian cases deal with the "as if enacted in this Act" formulation, Commonwealth Aluminium Corporation v. A.G., [1976] Qd. R. 231, and West Lakes Ltd. v. South Australia (1980), 25 S.A.S.R. 389, but in both cases the real issure was a manner and form question and consequently there are only dicta on the effect of the clause on third parties. However, in West Lakes it is of note that the plaintiff was attempting to restrain not only the parties but all Ministers of the Crown. In response to this point there was some division of opinion on the bench. King C.J. opined at 398 that the indenture had "the force of law" and that the "indenture binds the parties including the executive government of the State", while at 408 Zelling J. stated that "all the Ministers of the Crown of South Australia are not bound by the provisions of the two indentures." 
final class of agreements however the agreement loses even that importance and comes to represent nothing more than a policy statement or a set of drafting instructions for the legislation. In such a case the agreement may not be referred to in the statute at all or it may merit only a passing preambular reference. An instance of the former is the Australian offshore agreement, ${ }^{182}$ the only evidence of which is a brochure circulated by the Commonwealth Attorney General. Important instances of the latter are the agreement between the Commonwealth and New South Wales on the coal industry ${ }^{183}$ and the many agreements in both Canada and Australia on the regulation of the marketing of agricultural products. Arrangements of this sort are an essential element of many of the conditional grants used in Australia.

For these sorts of arrangements, the existence of an agreement is simply a point of departure and will provide little comfort to third parties or even assistance to a court in its job of interpretation. An instance is the Australian offshore arrangement and the case of Port MacDonnell Professional Fishermen's Association v. South Australia. ${ }^{184}$ The plaintiffs in the case were contesting the validity of a state-Commonwealth arrangement pursuant to which state fisheries legislation applied in the offshore. The only question that concerns us here relates to the argument that state laws could not have been intended to apply east of the equidistance line between Victoria and South Australia. That argument was ultimately accepted by the court after some speculative references to the intentions of the parties to the offshore arrangements. It is hard to escape the conclusion that the court would have been better placed to handle this problem had it had access to the terms of the agreement to which the legislation was purporting to give effect.

The dominance of the legislative regime is well illustrated by Duncan ${ }^{185}$ which concerned the Joint Coal Authority established by the State of New South Wales and the Commonwealth. In fact, although the court spilled a lot of ink on the subject of the ability of the two governments to enter into agreements to create joint authorities, in the end it did not appear particularly relevant. As Mason J. stated: ${ }^{186}$

In any event it is the validity of the Commonwealth Act that is in question, rather than the validity of the agreement. If the Commonwealth Act be valid, then it is difficult to perceive any ground for concluding that the agreement is invalid. And it is equally difficult to suppose that the invalidity of the agreement would affect the Commonwealth Act, assuming it to be otherwise within power (cf. Magennis...)

Chief Justice Gibbs was even more specific. ${ }^{187}$

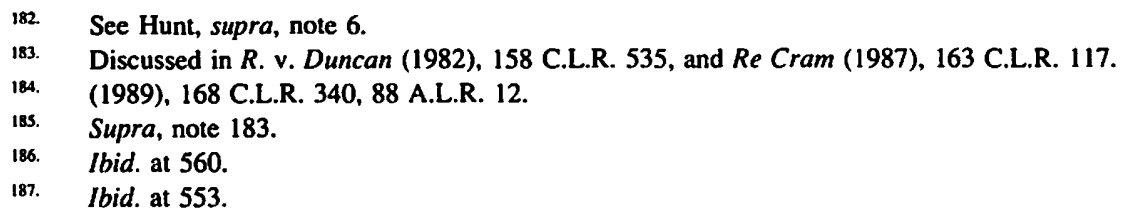


The Tribunal is constituted by statutes, rather than by the arrangement between the Governor-General and the Governor. The terms of the arrangement can have nothing to say as to the powers of the Tribunal, since, once an arrangement is made, and a person has been appointed to constitute the Tribunal, the powers and functions of the Tribunal will depend entirely upon the provisions of the statutes.

In relation to this class of agreements it is therefore quite meaningless to talk about the agreement as having any effect on third parties. The statutes dominate and the agreement is not even available as an aid to interpretation.

\section{Summary and Conclusion}

The courts have accorded a wide power to governments to enter into agreements with subjects and this same power applies to intergovernmental agreements. The only restrictions on this power exist by virtue of specific constitutional and statutory provisions. The resulting agreements however will bind only the governmental parties and will not affect third parties in the absence of some form of statutory approval.

It is clear that mere statutory approval of an agreement, whether prospective or retrospective, will not suffice to bind third parties. This formulation will certainly resolve any doubts there may be as to the authority to enter into the agreement and may cure some common law defects in the contract, but it does not change the law of the land and it would not appear to transform a contractual duty into a statutory duty.

In order to change the law of the land and thereby affect third parties, specific statutory language must be adopted; the more specific the language the more likely that third parties will be taken to be affected. It appears that the "as if enacted" language will suffice for this purpose, but none of the authorities on the point is strong. In my opinion it is appropriate that there should continue to be doubts about the effect of this formulation in relation to third parties. While it may indicate that parliament has directed its mind to the effect of the instrument, there is nothing in the formulation itself to suggest that it has directed its mind to particular statutory discretions or the particular ways in which third party rights may be affected. If there are doubts they should, as a matter of policy, be resolved in favour of the third party. Nevertheless, I think it is clear that the formulation must succeed in adding statutory duties to the contractual duties of the parties although the consequences in particular instances will be far from clear. The cases suggest that difficult questions will arise in the context of general enactments. Is the agreement "law" or "Commonwealth law"? Is a decision under the agreement a "statutory decision" or "authorized by statute"? These cases will be hard primarily because the documents in question were drafted not as statutes but as agreements and attempts to construe them as statutes will therefore always be hazardous. One conclusion that flows from these comments is that governments should be extremely wary of adopting the "as if enacted" language, for it is in effect a fiction and to enact a fiction is to invite distortion.

Doubts also exist as to the suitability of the other main formulation, that being approval accompanied by statutory empowerment or the imposition of statutory duties. In my opinion the better view must be that very specific statutory language is required. For this 
reason I do not regard the British Columbia Anti-Inflation Case as strong authority, for it fails to meet the test. At no point did the statute in question state that third parties would be bound, for it was primarily concerned with the ambit of the agreement and its "manner and extent." Similarly, if an agreement is to change the basis on which a governmental official is to exercise a statutory discretion (such as in Ansett) it would be a salutary exercise for the negotiators to identify these powers specifically and either include them in the enactment or identify in the enactment which sections of the agreement purport to change statutory powers.

The problems associated with the indirect effect of these agreements on third parties are completely avoided by the fourth category of agreement. Not only is there no attempt to give objective validity to an agreement, the only operative documents are the statutes which are drafted as such and will clearly identify the parties that are to be bound. In many respects therefore this approach is to be preferred for it brings the advantages of clarity and simplicity. However, it is not free from problems. Doubts still arise as to the application of other legislation and as to the appropriate forum for reviewing decisions made by jointly constituted boards. Ambiguities in the legislation may have to be resolved without reference to the agreement but there is no reason, even with this type of arrangement, why the agreement should not be scheduled to the statutes and an indication given that the statutes are intended to give effect to it.

\section{THIRD PARTY RIGHTS}

So far in this section we have concerned ourselves with the extent to which third parties may have obligations imposed upon them by agreements. We have accepted that this can only occur by way of statutory confirmation, but what about the question of rights? Is it possible that a third party may obtain directly enforceable rights as a result of an intergovernmental agreement in the absence of, or quite irrespective of, statutory confirmation?

The question arose in the Prince Edward Island Ferries Case ${ }^{188}$ in a way which suggests that its disposition had little to do with the fact that the agreement in question was constitutionalized. The matter came up in the context of calculating the damages that might be payable to the province for disruption of the ferry service, but it was certainly not necessary for the disposition of the appeal. All the members of the Court of Appeal were of the view that a third party claim for damages would have failed and that the province was only entitled to the damages that it suffered qua government. Different reasons for the conclusion were offered, but no member of the court relied upon the doctrine of privity. This is somewhat surprising but is probably explainable by the fact that the court preferred to see the duty as statutory rather than contractual. Two members of the court would have rejected a third party claim on the basis that the governments

188. Prince Edward Island v. Canada, [1976] 2 F.C. 712 (T.D.), rev'd on the damages issue at [1978] 1 F.C. 533. A more recent decision on the Terms of Union did not consider third party interests but there was a public interest intervener in the case: Re Minister of Transportation and Public Works of Prince Edward Island and Canadian National Railway (1990), 71 D.L.R. (4th) 596 (F.C.A.). 
could not have intended to give subjects a private right of action ${ }^{189}$ while the chief justice preferred to ground himself upon the war reparations cases. ${ }^{190}$ The case therefore serves to emphasize that the individual litigant faces obstacles of both doctrine and intention.

The most important Canadian case on the topic is the reference decision A.G.B.C. v. Esquimalt and Nanaimo Ry. Co. ${ }^{191}$ The Terms of Union of British Columbia obligated Canada to complete the railway to the Pacific within 10 year of the union. This obligation was not fulfilled and there was a serious dispute between the two governments on the matter until 1883. In that year a compromise was agreed upon and implemented by reciprocal legislation. The federal statute provided that "the agreement... is hereby approved and ratified, and the Governor in Council is authorized to carry out the provisions thereof according to their purport" while the provincial legislation stated that the agreement was "ratified and adopted." So far as is relevant here the agreement provided that the province would hand over a land grant to the Dominion which would then be conveyed to certain contractors who were proposing to undertake the construction of the Esquimalt and Nanaimo Railway under a provincial charter. The contractors were aware of the details of the arrangement and were closely consulted because their willingness to undertake the project depended very much upon terms that were offered by both governments. ${ }^{192}$

In addition to the federal-provincial agreement there was also a second formal agreement between the Dominion and the contractors for the construction of the railroad. Once again it can be inferred that the third party, this time the province, knew of these arrangements. ${ }^{193}$ There was no written agreement between the province and the contractors. Section 27 of the provincial ratifying legislation was the subject of the reference:

The lands to be acquired by the Company from the Dominion Government for the construction of the Railway shall not be subject to taxation, unless and until the same are used by the Company for other than railroad purposes, or leased, occupied, sold, or alienated.

The tax exemption was subsequently extended and confirmed by provincial legislation when the railway rights were leased to the C.P.R. The issue put before the courts was whether or not the initial contractors or the company could claim a contractual right, as

[1978] 1 F.C. 533, Le Dain J.A. at 589 and Pratte J.A. at 576.

lbid. Jackett C.J. at 556, note 30. His lordship referred to Kinloch v. Secretary of State for India (1882), 7 App. Cas. 619 (H.L.); the other case he probably had in mind was Civilian War Claimants Association v. R., [1932] A.C. 14 (H.L.).

[1948] S.C.R. 403, rev'd [1950] A.C. 87. Similar issues of contract and agency. arose in John Cooke \& Company v. Commonwealth (1922), 31 C.L.R. 394, aff'd (1924), 34 C.L.R. 269 (P.C.), this time in the context of dealings between the Commonwealth and Imperial governments. The applicant third parties were similarly unsuccessful although the courts were far less willing than in the Canadian case to conclude that there might be an agreement between the governments that was cognizable before a domestic court.

Ibid. per Locke J. at 419.

Ibid. at 417 per Locke J. 
opposed to a legislative right, to the exemption. Nobody questioned the power (at least as against the company) of the province to repeal the tax exemption ${ }^{194}$ but the parties wished to have its contractual status resolved. The Supreme Court, in particular, in answering the question seems to have inquired more broadly to see whether there was any basis in the private law of obligations for the company's claim.

The Supreme Court of Canada and the Privy Council were unanimously of the view that there was no contractual relationship between the contractors and the province. Instead there were two quite separate contractual relationships, one between the province and the federal government and the other between the contractors and the federal government. ${ }^{195}$ The Supreme Court, however, was of the view that contractual obligations were owed by the province to the company; in support of this proposition two different lines of reasoning were offered.

The contractual analysis was preferred by Mr. Justice Locke. ${ }^{196}$ He was of the view that the provincial legislation could be seen as an offer to the company that if the railway were built on the terms laid out in the ratifying legislation, then the company would be entitled, as matter of contract, to the tax exemption. ${ }^{197}$ Rand J. also accepted this analysis and Kellock J. would have accepted it in the alternative, but both he and Estey J. preferred to base themselves on a trust.

In Kellock's view the Dominion was constituted a trustee of the lands for the benefit of the company by the federal-provincial agreement: ${ }^{198}$ "the lands together with the immunity from taxation were the subject of a contractual obligation between the province and the Dominion as to which the latter was a trustee for the company upon fulfilment of the terms by the company. ... The company as beneficiary would accordingly be entitled to sue the province on the contract, it being necessary only that the Dominion should, in any such action, be made a party..."

In view of the fact that the agreement is, in some sense, constitutionalized because it represents an amendment to the Terms of Union of 1871 it is surprising that the company did not argue that the agreement constituted a limitation on power. This omission may be explained by the unusual way in which the case originated as a reference.

195. Rand J., ibid. at 439 does seem to have had some doubts as to the status of the federal-provincial relationship, preferring to view it as a political arrangement rather than a contract. The rest of the court and the Privy Council seem to have accepted its binding contractual character.

It should be noted that this pattern of analysis neatly avoids the privity problem. Indeed it does not seem to have been argued that the privity rules should not apply in this sort of case. Could it have been argued that statutory approval dispensed with the rule of law and that it was simply a matter of intention whether or not the parties intended to benefit a stranger? Part of the problem, no doubt, was that the original agreement was with the promoters who were to secure the incorporation of the company to build the railway and the claim was now being made on behalf of the company. For an analogous case see Placer Development, supra, note 133 esp. per Windeyer J. (diss.).

197. Ibid. at $426-28$.

198. Ibid. at 452. Estey's opinion on the trust issue is at 461 . The position of counsel for the Dominion on the hearing before the Privy Council is not without interest. At 106 A.C. "There is certainly an agreement between the Dominion and the province, and no question of any want of power. It was an implied term... that the province should not derogate from its grant. The Dominion took the island belt and the benefit of the implied terms on trust for the Respondent." 
The Privy Council rejected both sources of obligation, characterizing the company's entitlement as purely statutory in nature. The contractual analysis was rejected primarily on the grounds of intention. ${ }^{199}$ While it would no doubt be possible for parliament to pass an act which was to be construed as an offer by the executive to a subject, that was not very likely and there was no room to imply such an offer here. A similar analysis disposed of the trust obligation. The Privy Council thought it "highly improbable" that the Dominion would agree to act as a trustee for a subject; they explained the use of trust language in the provincial legislation by concluding that the Dominion might owe trust duties to the province to use the land transferred in the way that the agreement contemplated. ${ }^{200}$

The only other litigation in which this sort of analysis has been pursued is Gardner v. Ontari $^{201}$ where the issues arose on a motion to strike. The plaintiff Indian band was party to a treaty with the Dominion pursuant to which the Dominion agreed to set apart reserves. Subsequent litigation ${ }^{202}$ between the Dominion and the province of Ontario established that the Dominion was unable to fulfil its obligations without the concurrence of the province. This was obtained and evidenced by a federal-provincial agreement which was ratified by reciprocal legislation. Some years later the province passed further legislation purporting unilaterally to change the terms of the agreement. The band sued the provincial Crown arguing in the alternative that the provincial statute was ineffective or that, if effective, it was entitled to damages for loss of reserve rights. The province moved to strike out key sections of the statement of claim arguing that since the band was not a party to the agreement it had no right to complain about its breach. The band countered the privity argument by suggesting that its action against the province could be based either upon agency principles (that the Dominion Crown acted as its agent in the negotiation of the agreement) or trust principles (that the Crown whether in right of the Dominion or province owed trust duties to aboriginal people that had been breached by the legislation). Although the trial judge found that the pleadings were defective on both points he refused to grant the province's application, ruling that there was sufficient legal basis in both arguments to await trial of the action however difficult it might be in practice to constitute the Crown as agent or trustee..$^{203}$

In terms of result neither of these cases is particularly helpful to third parties aggrieved by the breach of an intergovernmental agreement. Their real significance here lies in their articulation of a cause or causes of action that may credibly be argued by a third party. Although it will always be difficult to overcome the preliminary hurdle that governments never intended to contract for the benefit of specific third parties, it is not difficult to imagine situations in which these sorts of issues might arise. Imagine for example a

199.

[1950] A.C. 87 at 110.

Ibid. at 110-111.

(1984), 45 O.R. (2d) 760 (H.C.).

St. Catherine's Milling and Lumber Co. v. R. (1888), 14 App. Cas. 46 (P.C.).

The trust point of course seems much more credible now in light of recent decisions of the Supreme Court of Canada including Guerin v. R., Sparrow v. R. (supra, note 12), and Mitchell v. Peguis Indian Band, [1990] 5 W.W.R. 97 esp. per Dickson C.J. at 114-15. 
situation in which federal monies were transferred to a state for a particular type of school ${ }^{204}$ or for a particular category of hospital patient and the monies were actually spent for other purposes.

\section{CONCLUSIONS}

This paper began with the argument that co-operative federalism, while essential for the efficient operation of a federal state, may have unfortunate consequences for citizens and may undermine important principles underlying our system of government. If that is the case, as I believe it to be, the important challenges become how to make the structures of co-operative federalism more accountable and how to empower individuals in the face of more complex and bigger government. Many of the responses to these challenges will of necessity focus upon the political process, but in this paper I have attempted to consider the legal issues. In particular I have focused upon two: the capacity of individuals to question the validity or implementation of an intergovernmental agreement and the extent to which third parties may be affected by such agreements.

The research reveals that the courts have been particularly slow to allow third parties to challenge intergovernmental agreements in the absence of a constitutional basis for the attack. Serious difficulties have been posed by the traditional doctrines of privity and parliamentary sovereignty and the law of standing. I have suggested two means of dealing with these problems. First, I have suggested drafting techniques making performance conditional upon the adoption of implementing legislation and permitting the agreement to be used as an aid in the interpretation of the implementing legislation. These techniques are suggested by the Gilbert, Lofstrom and Murphy, and Le Blanc decisions. My second proposal is suggested by the Finlay decisions. Both the decision on the merits and the decision on standing in that case confirm that intergovernmental agreements are public as well as private law arrangements and that the law of standing is more attuned to dealing with the problem of third party challenges than is the law of privity. Finlay also suggests that the criteria for standing should be relaxed in this context as they have been in Canada for constitutional purposes.

The courts have been far more vigilant when considering the form of statutory approval that will suffice to make an intergovernmental agreement binding upon third parties or make it effective in changing the law of the land. However, the courts have not been completely consistent, as some of the Canadian anti-inflation decisions bear witness, and we are entitled to expect that they demand clear and explicit statutory language before agreements negotiated by the executive affect the rights or obligations of citizens.

At a comparative level we can say that intergovernmental agreements are common in both countries and that they serve similar purposes. The agreements vary in formality but tend to the more formal end of the spectrum in Canada. In Australia there seems to be a marked preference for the fourth, and less formal, category of arrangement that we 
identified. Two reasons may be suggested for this. The first relates to the Magennis case and the succeeding decisions on veterans' lands. These cases suggested that there were significant risks involved in being too explicit in an agreement, especially where the intention of the parties was to evade a constitutional restriction. Consequently, every effort was made to ensure that implementing legislation was capable of standing alone and was not in any way dependent upon the existence of an agreement. The second reason, which is related to the first, revolves around the conditional grants power found in $\mathbf{s .} 96$ of the Australian constitution. This section provides a conceptual alternative to the contract option, even though some commentators argue that the'acceptance of conditional grants creates something that looks much like a contract. ${ }^{205}$

Australian practice on the statutory ratification of agreements is more consistent than Canadian. Although, as Warnick and others have demonstrated, there is considerable variation in the language used for resource franchise agreements, the invariable language for Australian intergovernmental agreements is that of approval or authorization. Canadian legislatures have experimented with many different formulations: nowhere is this more apparent than in the provincial efforts to deal with the anti-inflation program.

Canadian courts seem more willing than their Australian counterparts to adapt rules of common law to suit the demands posed by intergovernmental arrangements. The clearest example lies in the more relaxed attitude to standing in Canada. There the courts have recognized, particularly in the case of intergovernmental agreements, that it may be in the interests of neither government to question the validity or mode of implementation of an agreement, but that the public still has an interest in ensuring the lawful behaviour of governments. Another example is provided by the greater willingness of Canadian courts to examine the pith and substance of legislative schemes; however, that Canadian tendency is less apparent in the context of co-operative schemes than it is for schemes of an individual legislature. On the whole one can say that the courts of both countries are extremely respectful of, and deferential towards, co-operative schemes. 